Playing with Art: Musical Arrangements as Educational Tools in van Swieten's Vienna Author(s): Wiebke Thormählen

Source: The Journal of Musicology, Vol. 27, No. 3 (Summer 2010), pp. 342-376

Published by: University of California Press

Stable URL: http://www.jstor.org/stable/10.1525/jm.2010.27.3.342

Accessed: 07/05/2013 19:04

Your use of the JSTOR archive indicates your acceptance of the Terms \& Conditions of Use, available at http://www.jstor.org/page/info/about/policies/terms.jsp

JSTOR is a not-for-profit service that helps scholars, researchers, and students discover, use, and build upon a wide range of content in a trusted digital archive. We use information technology and tools to increase productivity and facilitate new forms of scholarship. For more information about JSTOR, please contact support@ jstor.org. 


\title{
Playing with Art: Musical Arrangements as Educational Tools in van Swieten's Vienna
}

\author{
WIEBKE THORMÄHLEN
}

\begin{abstract}
We have the honour of announcing that the Creation, which was recently issued in score, may now be had not only in quintets for 2 violins, 2 violas and violoncello arranged by Hrn. Anton Wranizky, but also for the klavier or fortepiano with all vocal parts arranged by Hrn. Sigmund Neukomm with every precision, energy and great fidelity to the beauties and originality of the full score.
\end{abstract}

Wiener Zeitung

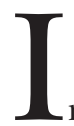

March 1800 , the Viennese publisher Artaria issued this announcement in the Wiener Zeitung, offering Joseph Haydn's Creation arranged for string quintet. It is clear in a letter Haydn sent to Georg August Griesinger in October 1801 that the composer approved of this arrangement: he applauded Anton Wranitzky's skill in producing it and suggested that he should be invited to arrange The Seasons as well. ${ }^{1}$ What is more, Haydn's letter shows that the question

The epigraph is from the Wiener Zeitung, 24 (180o); quoted and trans. in H. C. Robbins Landon, Haydn: Chronicle and Works: The Years of "The Creation," I 796-I80o (Bloomington: Indiana University Press, 1977), 542 .

1 "As far as the arrangement of the Seasons for quartet or quintet is concerned, I think that Herr Wranizky, (Kapellmeister) at Prince Lobkowitz, should receive the preference, not only because of his fine arrangement of the Creation, but also because I am

The Journal of Musicology, Vol. 27, Issue 3, pp. 342-376, ISSN 0277-9269, electronic ISSN $1533-8347$. (C) 2010 by the Regents of the University of California. All rights reserved. Please direct all requests for permission to photocopy or reproduce article content through the University of California Press's Rights and Permissions website, http://www.ucpressjournals.com/reprintInfo.asp. DOI: $10.1525 /$ jm.2010.27.3.342. 
was not whether these arrangements should be made, but rather who should make them. Haydn, in this case, chose a former student who had since assumed a post as Kapellmeister of Prince Lobkowitz's private orchestra, and who enjoyed high esteem in Viennese society as a violin virtuoso and pedagogue.

Even a cursory glance at European publishers' catalogues suggests that the production and sale of arrangements were commonplace, but the routine production of large-scale vocal works in versions for string quartet and string quintet was a practice peculiar to Austrian publishers. In England, for instance, publishers offered the customary piano reductions and vocal extracts, as well as versions of complete operas and oratorios for one or two flutes. String quartet versions of vocal works did not appear there until the nineteenth century and never enjoyed the same popularity as in Austria, although arrangements of symphonies for quintet became fashionable following J. P. Salomon's popular arrangements of the London symphonies. ${ }^{2}$ On the Viennese market, symphonies offered in quartet and quintet arrangements were advertised in publishers' catalogues alongside original compositions under the rubric "Quartetten" or "Quintetten." Arrangements of vocal works, however, were commonly listed in separate categories. Piano reductions were classed apart from individual arias arranged for voice and keyboard, and arrangements of vocal works for a purely instrumental ensemble were listed separately, again according to the number of players. ${ }^{3}$ Within the latter categories, we can detect a change in

sure that he will not make use of it to further his own ends." Letter from Joseph Haydn to Georg August Griesinger Oct. 1, 1801; quoted and trans. in H. C. Robbins Landon, Haydn: Chronicle and Works: The Late Years: I $80 I-1809$ (London: Thames and Hudson, 1977 and 1994), 79-8o.

2 For arrangements in England, see Christopher Hogwood, "In Praise of Arrangements: the "Symphony Quintetto,"” in Studies in Music History: Presented to H. C. Robbins Landon, ed. Otto Biba and David Wyn Jones (London: Thames and Hudson, 1996), 82-104. A similar picture emerges from a preliminary study of French publishers. A comprehensive bibliographical study of the sale of large-scale works arranged for the chamber does not yet exist, although select features of the practice have been illuminated by Hogwood and Wheelock. See Gretchen Wheelock, "Marriage à la mode: Haydn's Instrumental Works 'Englished' for Voice and Piano," Journal of Musicology 8 (1990): 357-97. Studies in the dissemination of music by Haydn and Mozart shed some light on the practice of arranging without, however, giving it attention either as a significant feature in the dissemination of their music or even as an artistic practice in its own right. See David Wyn Jones, "From Artaria to Longman \& Broderip: Mozart's Music on Sale in London," in Studies in Music History: Presented to H. C. Robbins Landon, $105^{-1} 4$; and Wyn Jones, "Haydn's Music in London in the Period 1760-179o," Haydn Yearbook 14 (1983): 144-72.

3 See, for example, the Verzeichnis alter und neuer sowohl geschriebener als gestochener Musikalien, welche in der Kunst- und Musikalienhandlung des Johann Traeg, zu Wien, . . . zu haben sind (Vienna, 1799). This source includes symphonies arranged for quintet and quartet among the listings of originals under the categories "Quintetti à 2 Viol. 2 Viole e Vllo" and "Quartetti à 2 Viol. Viole e Vllo"; also in the main section "Cammer-Musik" (rather than "Theatral-Musik"), Traeg lists a separate category "Quintetti aus Opern und Ballets 
fashion from selected hits advertised as "Overturen und Arien aus verschiedenen besten Opern gezogen, und in Quartetten gesetzt" toward complete works catalogued as "Arien, Overturen und ganze Operen in Quartetten."4 Mozart's Die Entführung aus dem Serail and Die Zauberflöte, his Don Giovanni, Figaro, and Cosi fan tutte, and even the opere serie Idomeneo and Clemenza di Tito were available to Viennese music lovers in arrangements for string quartet and quintet (see fig. 1); and by 1815 , both Wellington's Victory and Fidelio had been issued in quintet transcriptions. 5 An arrangement of The Creation for Harmoniemusik had begun to circulate in Vienna shortly after $1800,{ }^{6}$ whereas an arrangement for string quartet, prepared by Ignaz Franz v. Mosel, was published by T. Mollo in 1805 . An arrangement for piano trio by Charles Zulehner was offered through Traeg in Vienna in 1807.7

These arrangements catered to a rapidly growing market of amateur and dilettante musicians among the aristocratic, bureaucratic, and merchant classes; they were a lucrative business for publishers and arrangers, and they helped perpetuate a composer's popularity at home

für verschiedene Instrumente arrangiert," which contains mainly arrangements for flute quintet with the exception of Cosi fan tutte and Le nozze di Figaro, which are offered in arrangements for two violins, two violas, and violoncello. Similarly, he has a separate category "Quartetti aus Opern und Ballets für 2 Viol, Viole e Vllo arrangirt." Arrangements of opera and ballet for flute quartet are listed in a separate category. Both lists offer arrangements of Haydn's Armida, La Vera Costanza, Mozart's Zauberflöte, Entführung, and Don Giovanni. In Traeg's subsequent catalogue of 1804, the arrangements of both The Creation and The Seasons appear for string quartet and for string quintet. See "Erster Nachtrag zu dem Verzeichnisse ... des Johann Traeg” (Vienna, 1804), 10.

4 These categories are quoted from the "Verzeichnis von Musikalien, welche bey Artaria \& Compagnie . . . zu haben sind. Im May 1785 " and "Im Jäner 1788 ," respectively. See Otto Biba ed., Die Sortimentskataloge der Musikalienhandlung Artaria $\mathcal{E}^{\circ}$ Comp. in Wien: aus den Jahren I779, I $780, I_{7} 82, I_{7} 85$ und I 788 (Tutzing: Hans Schneider, 2006), 95, 136,243 , and 268 .

5 C. F. Whistling and Hofmeister, ed., Handbuch der musikalischen Literatur oder allgemeines systematisch geordnetes Verzeichnis gedruckter Musikalien, 2nd ed. (Leipzig: in Commission by Anton Meysel, 1817 ; repr. New York: Garland, 1975).

${ }^{6}$ Manuscript parts of The Creation arranged for Harmonie by the timpanist Georg Druschetzky survive at the Gesellschaft der Musikfreunde in Vienna (A-Wgm, VIII 40509). Pleyel published an arrangement for Harmoniemusik in 1802; Wolfgang Suppan suggests that a Harmonie arrangement was prepared from Haydn's autograph for the GrenadierKompagnie in Eisenstadt, which Haydn was in charge of and which had been refounded after a three-year intercession in 18 oo. Wolfgang Suppan, "Die Harmoniemusik-Das private Repräsentations- und Vergnügungsensemble des mitteleuropäischen Adelszwischen Kunst und gesellschaftlichem Gebrauchswert," in Musica Privata, ed. Monika Fink, Rainer Gstrein, and Günter Mössmer (Innsbruck: Edition Helbling, 1991), 151-65.

7 Anthony van Hoboken, Joseph Haydn: thematisch-bibliographisches Werkverzeichnis, vol. 2: Vokalwerke (Mainz: Schott, 1971), 43. It seems that the quintet arrangement enjoyed the most popularity as it was reprinted by Sieber in Paris; Simrock in Bonn offered a quintet arrangement around the same time. See Hoboken, Werkverzeichnis, 42-43. Wranitzky's arrangement was also reprinted in London and advertised in March 1800 , possibly to coincide with the work's first public performance in the city. 
FIGURE 1. C. F. Whistling and Hofmeister, ed., Handbuch der musikalischen Literatur oder allgemeines systematisch geordnetes Verzeichnis gedruckter Musikalien, 2nd ed. (Leipzig: in Commission by Anton Meysel, 1817; repr. New York: Garland Publishing, 1975), 66. (C) British Library Board M.R.Ref. 1.a.1

\section{V. Quartetten fuer die Violine.}

Mosart (W. A.) Collection complette de ses Quatuors et Quint. et 1 Trio. 5 Volumes cartunnés. Papier Jésus Véliu. (100 Fr.) Grand Papier Colombier Vélin (15o Fr.) Paris, Pleycl.

- Collection complette des Quatuors, formant 27 Quat. avec le Portrait de lAnteur. 4 Volumes brochés. Paris, Sieber P. 72 Fr.

- Ocuvres choisies, contenant 10 Quat. 8 Quint. et 1 Trio. Numérutées, avec le Portrait de l'Auteur et un Catologue thèmatique, Papier Vélin, cartunuées. Paris, Janet et C. 9o Fr.

- Oeturres complettes (12 Quatuors.) 4 Cahicrs. Leipz. Br. et Haertel 2 i 2 Thl.

- Collectiou de tous les Quatuors, Quint. Trios et Duos. Partio 1. Wien, Artaria 2 i Fl.

- Collection d'Opéra arr. Partie 2. Wien, Artaria 24 Fl.

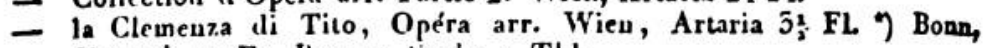
Simrock $12 \mathrm{Fr}$. Eratus. Spelir 2 Thl.

- Cosi fall tutte, Opíra arr. Wien, Artaria 4 Fl. Wien, Steiner 5 Fl.

- Don Juan, Opéra arr. Wieu, Artaria 5 Fl. (Liv. 1, 2.) Bunn, Sinnock à $10 \mathrm{Fr}$. Amsteril. Hummel a is Fl. Paris, Pleyel a to Fr.

- I'Eulévement du Serail (die Entfuehrung aus dem Serail,) Opéra arr. Wien, Artaria 4 Fl. Buan, Simruck 15 Fr.

- Idoneneo, Opéra itr. Wicu, Attaria 2 Fl. is 8 Xr. Fltw. Zulehner $8 \mathrm{Fl}$

- le Nonze di Fiñaro, Opéra arr. Wien, Artaria 4 Fl. Brauns. Spehr 2 Thl. (Liv. 1. 2.) Bum, Simrock a 12 Fr.

- die Zauberfloete, Oper arr. 2r Theil. Wien, Artaria 3 Fl. 24 Xr.

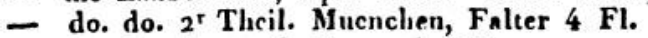

- lo. do. Amsterd. Hummel 4 FI.

- Airs de la Flùte enchantće arr. Paris, Pleycl 12 Fr.

- Ouverture et Airs de la Flùte escliantée arr. Paris, Sieber P. g Fr.

- Ouvertures arr. des Opéra: Don Juan, Titus, Cosi fan tutle, Figaro, die Entfuehrung, dic ZaubcrAuetc. Wien, Artaria 3 Fl.

and his renown abroad. ${ }^{8}$ More significantly, they occupied an important place within late-eighteenth-century aesthetic and social discourses, which held that art's purpose was the moral education of man. The purpose of arrangements was to inspire social interaction in and through

8 Musicologists have traditionally held the belief that arrangements are merely marketing ploys, a view that has only been partially revised by the studies cited in note 2; arrangements continue to be considered as sources irrelevant to the "work." See, for example, Armin Raab, "Kritischer Bericht," Joseph Haydn Werke 28/4, "Die Jahreszeiten," ed. Armin Raab (Munich: G. Henle, 2007), Teilband 2:573: "Das von August Eberhard Müller erstellte Arrangement für Streichquintett (B\&H, Leipzig, 1802) könnte zwar unabhänging von (der Originalausgabe) auf der von Haydn nach Leipzig geschickten Stichvorlage beruhen, wurde aber als Bearbeitung für die Edition nicht herangezogen." 
art; their popularity went hand in hand with the belief in humans' innate senses of sociability and of morality, both of which were trained best through engagement with natural and artistic beauty. 9 Arrangements of operas and oratorios for an instrumental chamber ensemble bridged the gap not only between genres but between those moral ideologies that had traditionally upheld vocal music and the newer ones that heralded instrumental music as equally viable for the moral education of the individual. ${ }^{10}$

In Austria, Gottfried van Swieten, President of the Court Commission on Education and librettist of The Creation, was instrumental in rethinking the position of art in the formation of an Austrian society and the education of its individuals. In a remarkable series of lectures, he argued that art had to be malleable and adaptable so as to fulfill its purpose, because only the pleasurable repetition of the material of art would grant the honing and education of the inner sentiments. In his lectures he stressed the need to experience an object of art in a variety of guises, to engage with it repeatedly, and, if at all possible, be actively involved in its performance-requirements that were met by offering arrangements of large-scale works for domestic performance.

Arrangements of vocal music for instrumental chamber groups also engaged with the wider discourse on the meaning of instrumental music and its status within the arts. The overwhelming majority of theorists in the last third of the eighteenth century still maintained that instrumental music was inferior to vocal music. ${ }^{11}$ If art's purpose was the

9 This belief is directly related to the reception of Greek philosophy in the eighteenth century, which focused on Plato's writings. Although the differentiation between ethics, politics, and aesthetics-the good, the true, and the beautiful-is present in seminal form in Plato's writings, he develops them together, retaining the use of the single Greek word kalos ( $\kappa \alpha \lambda \varsigma_{\varsigma}$ ) for all three. Eighteenth-century thinkers took this as the starting point for their ideas of the unity of the good, the true, and the beautiful.

${ }_{10}$ The gradual emancipation of instrumental music in the late eighteenth century has been discussed in Bellamy Hosler, Changing Aesthetic Views of Instrumental Music in Eighteenth-Century Germany (Ann Arbor: UMI Press, 1981); John Neubauer, The Emancipation of Music from Language: Departure from Mimesis in Eighteenth-Century Aesthetics (New Haven: Yale University Press, 1986); Nicolas Henri Waldvogel, "The Eighteenth-Century Esthetics of the Sublime and the Valuation of the Symphony" (PhD diss., Yale University, 1992); the idea that the string quartet becomes the "realization of one of the highest goals of the Enlightenment" is argued in David P. Schroeder, Haydn and the Enlightenment: The Late Symphonies and Their Audience (Oxford: Oxford University Press, 1990).

11 "Bey diesem augenscheinlichen Vorzug der Musik über andre Künste, muß doch nicht unerinnert gelassen werden, daß ihre Würkung mehr vorübergehend scheinet, als die Würkung andrer Künste. Das was man gesehen, oder vermittelst der Rede vernommen hat, es sey, dass man es gelesen, oder gehört habe, läßt sich eher wieder ins Gedächtnis zurückrufen als bloße Töne.” So writes Kirnberger for Sulzer's Allgemeine Theorie der schönen Künste; in light of the general demands that art must have a lasting effect, this statement gives preference to vocal music. See Johann Philipp Kirnberger, "Musik," in Johann Georg Sulzer, Allgemeine Theorie der schönen Künste, rev. ed., 4 vols. (Leipzig, 1792-94; repr. Hildesheim: Georg Olms, 1994), 3:434. Sulzer solicited help from Kirnberger and Johann A. P. Schulz 
moral education of man, its moral concepts were best expressed in words that each particular art form accompanied with its own emotive signifiers. Music without text, however, lacked the facility to describe the object of emotions, merely yielding the emotion itself. ${ }^{12}$ In itself, instrumental music not wedded to a particular context, such as a march or a dance, failed to be morally instructive because its emotional appeal could not be allied with a distinct concept, and so could not be ordered into a system of moral value judgments.

Still, theorists recognized music's inherent emotional appeal and conceded that this was, at least in part, a physical force because music could "express even in inarticulate tones myriad passions" as it "sets the nerves in our body in motion." ${ }^{3} 3$ The widespread popularity of chamber musicmaking demanded a reevaluation of the art's effect on the individual's moral education, and this reevaluation had to take account of music's physical effect sparked through the act of playing and the act of listening. ${ }^{14}$

Van Swieten's theories on education were inspired in large measure by Northern German theorists, for example, Johann Georg Sulzer, and particularly by their writings on aesthetics. Despite the reliance of eighteenth-century music-aesthetic scholarship on Sulzer's Allgemeine Theorie der schönen Künste, the significance of the human body-and the location of the individual's senses of reason, moral sentiment, and taste within it—has been largely overlooked. Van Swieten's writings rely on the physical foundation of the human senses and sentiments articulated in Sulzer's monument to art; as such they bear witness to the fact that any understanding of aesthetics in the mid to late eighteenth century was still rooted in an understanding that emotions were located in the body, not the mind. As taste and moral sentiment were understood to be based in physical sensation, an actual physical engagement with

in composing the articles on music; in the following, all articles from the Allgemeine Theorie will be cited under Sulzer's name. For references to the general discussion of the parity between instrumental and vocal music in the eighteenth century, see n. 10.

12 Kirnberger explains this phenomenon with reference to functional music such as dances and marches: "Man kann in der That bey Tänzen, bey festlichen Aufzügen und kriegerischen Märschen, die Vocalmusik völlig missen, weil die Instrumente ganz allein hinreichend sind, die bey solchen Gelegenheiten nöthigen Empfindungen zu erweken und zu nähren. Aber wo die Gegenstände der Empfindung selbst müssen geschildert, oder kennbar gemacht werden, da hat Musik die Unterstützung der Sprache nöthig." "Instrumentalmusik," in Sulzer, Allgemeine Theorie, 2:677.

13 "Die ganze Musik gründet sich auf die Kraft, die schon in unartikulierten Tönen liegt, verschiedene Leidenschaften auszudrücken." "Instrumentalmusik," in Sulzer, Allgemeine Theorie, 2:677. Unless otherwise stated, translations are mine.

14 In literary studies, descriptions of music's physical effects receive attention within the discourse of sensibility in the eighteenth century. See, for example, J. G. BarkerBenfield, The Culture of Sensibility (Chicago: University of Chicago Press, 1992); in musicological studies, these effects received a long-overdue historical examination in Elizabeth Le Guin, Boccherini's Body: An Essay in Carnal Musicology (Berkeley: University of California Press, 20o6). 
art would enhance their effect. Arrangements of large-scale works, and of vocal works in particular, for one-to-a-part instrumental ensembles offered the actual physical and mental engagement with a particular piece of art; they returned another layer of meaning that extended beyond the moral feeling inscribed in the text by making the arrangement speak directly through the performers' bodies, thereby activating their inner senses. In the arrangement, any moral didacticism conveyed by the original's text was replaced by the inspiration of the individuals' inner senses in sociable negotiation with their fellow players.

\section{The Creation à Cinq: Rethinking Boundaries of Performance and Arrangement}

Haydn's willingness to concern himself with arrangements of his oratorios is demonstrated by his having taken the trouble to correct A. E. Müller's pianoforte reduction of The Seasons. Haydn pointed out where the arranger needed to go beyond mere transcription to suit the pianistic idiom: in order not to sound nonsensical, some textural features of the work required a composer's ingenuity in their reworking. He accompanied his corrections with the following letter to Müller:

Again I admire your talent and the enormous energy which you have hitherto expended on such a difficult task. The arrangement is easy, and readily comprehensible throughout, especially the final fugue. But I must ask you to include the changes I have sent you, if at all possible.

NB.: Since, because of the quick tempo, the storm in the 2nd part cannot possibly be played as it now stands, my suggestion would be to do it in the following way, so that the singers will find the right pitch more easily: viz.- you will see my suggestion on the enclosed sheet. ${ }^{15}$

The enclosed sheet gives an extract from the trio and chorus at the end of part 2 and notes:

In the last line, the first bars should read as follows. Although they are not in the score. NB! This whole passage, with its imitation of the frogs, was not my idea; I was forced to write this Frenchified trash. This wretched idea disappears rather soon when the whole orchestra is playing, but it simply cannot be included in the pianoforte reduction. ${ }^{16}$

Haydn's judgment adds artistic credence to the act of arranging itself, for he doesn't judge it solely for its craftsmanship and sensitivity to the performer, but also for its artistic merit.

${ }_{15}$ Haydn's letter to August Eberhard Müller, Dec. 11, 1801; quoted and trans. in Landon, Haydn: The Late Years, 88.

${ }^{16}$ Ibid., 89; Georg Feder, "Haydn's Korrekturen zum Klavierauszug der Jahreszeiten," in Festschrift Georg von Dadelsen, ed. Thomas Kohlhase and Volker Scherliess (NeuhausenStuttgart: Hänssler, 1978), 101-12. 
Haydn's consideration of the pianoforte reduction suggests that he treated this arrangement as a valid instantiation of the work alongside many others that differed considerably from each other. ${ }^{17}$ The Creation had appeared in score in four different languages within a year of its first publication in 1800 , and printed parts became commercially available in the following two years. ${ }^{18}$ Even the sources directly linked to the composer show very different versions of the work. The three manuscript scores with links to Haydn reveal different readings and corrections, and the four sets of parts used for early performances indicate that the composer sanctioned a huge range of performing forces. ${ }^{19} \mathrm{Re}-$ cords pertaining to the performances conducted by Haydn also paint a varied picture, thereby suggesting that Haydn's aural image of the work was far from fixed. Around 180 performers were reportedly involved in the first performance at the Palais Schwarzenberg on April 29, 1798, whereas the Budapest Royal Palace performance on March 8, 1800 , used only about a third of these forces; and when Haydn conducted The Creation in honor of Lord Nelson's visit to Eisenstadt in September 1800 , he used perhaps as few as twenty-four instruments and eight singers. ${ }^{20}$ And although Haydn and van Swieten revised and reviewed the engraver's score for the first edition of the work with unusual attention to detail, apparently neither was concerned that The Creation was frequently being

17 Recent efforts to establish a "Fassung letzter Hand" for The Creation are testimony to the existence of the work's wide variety of "original" instantiations. Joseph Haydn Werke 28/3, "Die Schöpfung," ed. Annette Oppermann (Munich: G. Henle, 2008). Oppermann cites a variety of sources, yet concludes that the Essler Stichvorlage for the first edition must be considered the "Fassung letzter Hand." That this conclusion is negotiable is illustrated not least in her previous articles in which she raises the question whether the lost autograph can and should be seen as the primary source. See Oppermann, "Schreibraum und DenkraumJoseph Haydns Skizzen zur 'Schöpfung'," Musikforschung $5^{6}$ (2003): $375^{-81}$; and Oppermann, "Vom Nutzen und Nachteil der Historie für den Leser: Wozu braucht man eine historischkritische Ausgabe der 'Schöpfung'?” Österreichische Musikzeitschrift 6o, nos. 6-7 (2005): 25-33.

18 The first edition included German and English text. Hoboken cites a French score published by Erard in 1800 , and another with French and Italian text published by Pleyel in 1801. Hoboken, Joseph Haydn: Werkverzeichnis, 2:37-38.

19 Three manuscript scores can be linked to Haydn and the early performances, in addition to four sets of parts. See Annette Oppermann, "Vorwort," Joseph Haydn Werke 28/3, "Die Schöpfung," ed. Annette Oppermann (Munich: G. Henle, 20o8), Teilband 1: $\mathrm{x}-\mathrm{xii}$ and xiv-xvii. While the Tonkünstler set includes four solo vocal parts, ten tenor, and ten bass choir parts, a part for the concertmaster, thirty-four further string parts, and parts for three "Harmonien," the other sets, corresponding to varying degrees with the other scores, contain considerably fewer parts: the estate parts include only two for each violin and cello, and only one for the viola. The woodwinds are represented by three flutes, two oboes, two clarinets, a bassoon part that is split, and one contrabassoon part; and there are two trumpets, two trombones, one bass trombone, and timpani. In addition to three solo voices there are two soprano parts, two altos, three tenors, and only one bass part. See also A. Peter Brown, Performing Haydn's "The Creation": Reconstructing the Earliest Renditions (Bloomington: Indiana University Press, 1986).

${ }^{20}$ Brown, Performing Haydn's "The Creation," in particular table 1: "Viennese Performances of The Creation to early $1810, " 3$. 
performed from parts and conducting scores that did not contain any of these revisions. ${ }^{21}$

If the enormous discrepancies between these myriad "performances" of The Creation - both in sound and in print-suggest a fluid and adaptable approach to the artwork, the arrangements of the work for string quartet and string quintet present a further set of issues. ${ }^{22}$ First, the arrangements raised questions of originality as they were advertised with the original composer's name on the title page alongside that of the arranger. Figure 2 shows the two names framing the page, one in elaborate lettering using capital and lowercase letters, the other using capital letters only. Here, original creator and arranger stood side by side, suggesting equality between the two, raising questions about authorship, and making the idea that the composer approved this publication even more noteworthy.

Second, one-to-a-part string chamber music had become the epitome of an art for connoisseurs mimicking the "conversation between four intelligent people." 23 Arrangements of vocal music for string quartet or quintet tapped into the recent fashion for the new medium while also jarring with it conceptually: the metaphorical conversation, which had become the content of the string quartet in particular, was undermined by the narrative structure that was retained in arrangements such as Wranitzky's for string quintet and Mosel's for quartet, which presented The Creation in its entirety-choruses, arias, accompanied recitatives. and even secco recitatives. ${ }^{24}$ Both the string quartet and the

${ }^{21}$ For an explanation of the revisions, see Annette Oppermann, "Vorwort," Joseph Haydn Werke, 28/3, Teilband 1: x-xii and xiv-xvii.

22 "Today, the words 'arranged by ...' are anathema to the scholars and a deterrent to many performers," Christopher Hogwood wrote in 1996 . He continues by noting that "in the fast-expanding world of commercial music-making at the turn of the eighteenth century, arrangement was for composers a way of life and for publishers a sure way of prospering; many of their better-wrought products could easily be taken into the repertoire of today's performers." See Hogwood, "In Praise of Arrangements," 83. This is a rare sympathetic account of arrangements (see also n. 2). The literature on eighteenthcentury arrangements is mostly restricted to the arrangements of works by canonic composers; see, for example, Marius Flothuis, Mozarts Bearbeitungen eigener und fremder Werke (Kassel: Bärenreiter, 1969); Flothuis, "Mozart bearbeitet und variiert, parodiert und zitiert," Mozart-Jahrbuch (1980-83): 196-207; and Imogen Fellerer, "Mozarts Bearbeitungen eigener Werke," Mozart-Jahrbuch (1952): $70-76$. The value judgment attached to these arrangements-implicitly by the lack of attention they receive and explicitly in the few scholarly engagements with the material-falls far behind recent revisions of the dichotomy between text and performance as a problematic of editing practices.

23 Goethe's letter has been invoked frequently in the explanation of the string quartet as a high art form, not least by Ludwig Finscher's seminal study of the string quartet. See Ludwig Finscher, Studien zur Geschichte des Streichquartetts I (Kassel: Bärenreiter, 1974), 19. The original quote is reprinted in "Letter to Zelter. 9.11.1829," Goethes Briefe, ed. Karl Robert Mandelkow, vol. 4 (Hamburg: Christian Wegner, 1967), 349.

${ }_{24}$ According to Heinrich Christoph Koch, the string quartet had become "diejenige Gattung der Sonate, die seit ohngefähr vierzig Jahren am allerfleißigsten bearbeitet worden ist.” Koch, "Quatuor,” Musikalisches Lexikon (Frankfurt am Main, 1802), 1210. 
FIGURE 2. Title page of "Die Schöpfung: Ein musikalisches Oratorium von Herrn Joseph Haydn übersetzt in Quintetten . . . von Herrn Anton Wranitzky." (Wien: Artaria E̋ Co., 1800). (C) Bayerische Staatsbibliothek München, Musikabteilung, Signatur: 4 Mus.pr. 37357

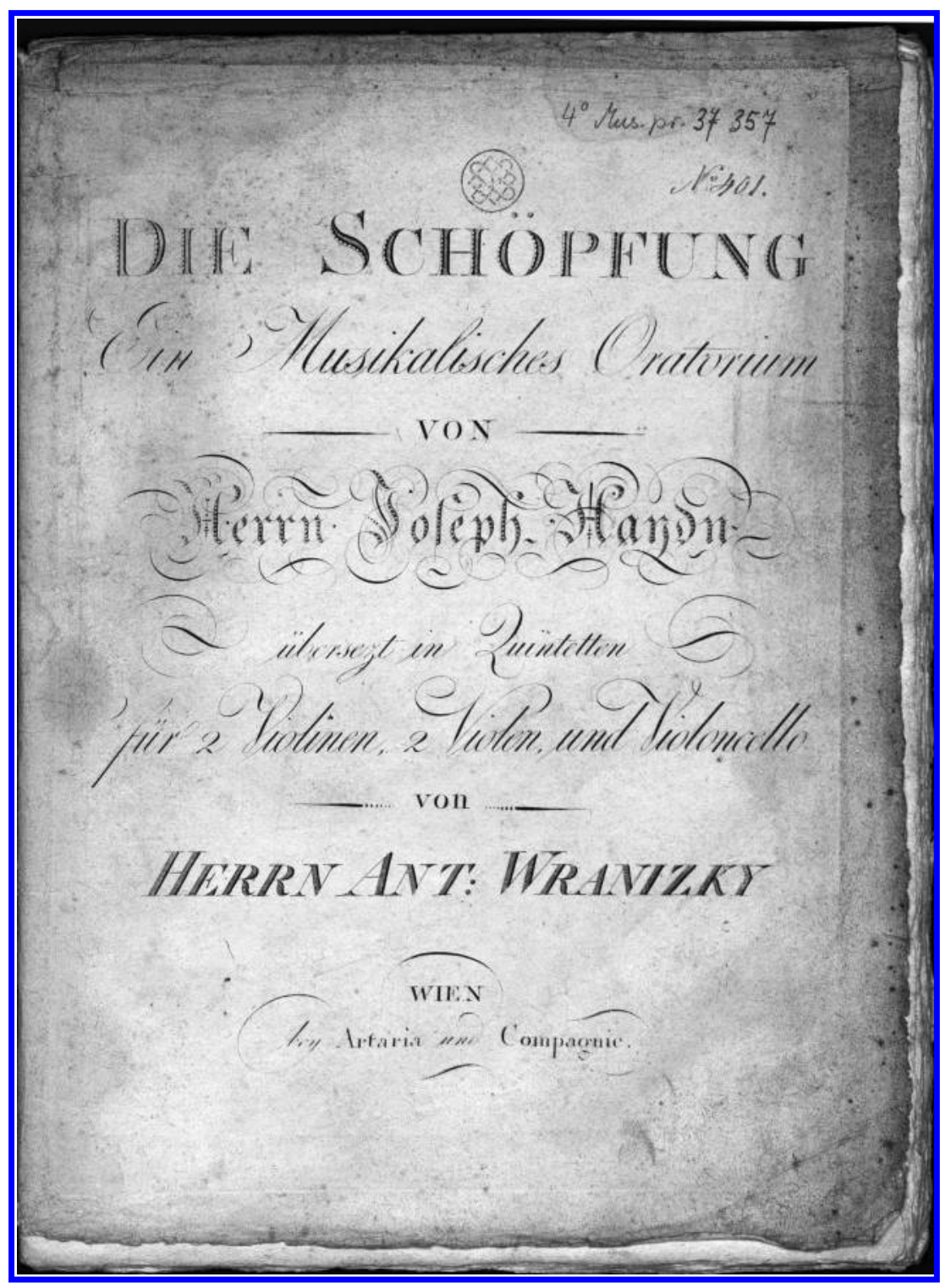


string quintet versions presented transcriptions of the vocal work into a solely instrumental medium, thereby combining the sound world and associations of chamber music for strings with the narrative expectations of opera and oratorio.

With respect to The Creation, the case becomes more interesting as reviewers of the "original" were quick to point out that what "is peculiar about it, is its complete independence of the language's effect." ${ }^{25} \mathrm{Re}-$ views frequently relegated the text of The Creation to a secondary position even-as this particular reviewer pointed out-in the recitatives. Vocal models had dominated instrumental composition throughout the eighteenth century, yet toward the end of the century they became subsumed into the compositional material as large-scale topics; within a musical language that was highly conventionalized, each gesture had acquired emotive meanings that no longer needed textual clarification. ${ }^{26}$ Haydn composed voiceless recitatives, successfully employing recitative-derived stock gestures in instrumental compositions including the second movement of Le Midi (Hob.I:7), the Adagio of the String Quartet op. 17 no. 5 (Hob.III:29), the Capriccio of the String Quartet op. 20 no. 2 (Hob. III:33), the Divertimento (Hob.II: 17 ), and-in combination with a conscious personification and dramatization of the soloist-in the Andante of the Sinfonia Concertante (Hob.I:105). ${ }^{27}$ Set within instrumental music that had never had textual connotations, these recitatives are startling and highly expressive passages, personalizing and characterizing the phenomenon of "the player" while also drawing attention to and relying on music's indeterminate yet powerful effect on the imagination.

25 "That which is peculiar and original about it, is its complete independence of the language's effect; it moves at its own pace and regards the telling of the story only as something of secondary interest. That is what occurs in the recitative describing the creation of the firmament." Allgemeine musikalische Zeitung 3, 289-96; quoted and trans. in Landon, Haydn: The Years of "The Creation," 588.

${ }_{26}$ That instrumental recitatives function beyond direct association with previously existing words and transcend the status of substitute for a slow introduction or an entire slow movement, as Paul Mies and Herbert Seifert had claimed, has been argued convincingly by David Charlton. See Paul Mies, Das instrumentale Rezitativ (Bonn: H. Bouvier, 1968); Herbert Seifert, "Das Instrumentalrezitativ vom Barock bis zur Wiener Klassik," De ratione in musica, ed. Theophil Antonicek, Rudolf Flotzinger, and Othmar Wessely (Kassel: Bärenreiter, 1975), 103-16; and David Charlton, "Instrumental Recitative: A Study in Morphology and Context, 1700-1808," Comparative Criticism 4 (1982): 149-68. Charlton claims, in particular, that these gestures or shapes coincide largely with those assembled by Sulzer in his article "Recitativ" in the Allgemeine Theorie der schönen Künste. Both display a consciousness of shape as a primary feature of expression; see Charlton, "Instrumental Recitative," $15^{1-52}$. Compare also the semiotic topics of classical music identified by V. Kofi Agawu in Playing with Signs: A Semiotic Interpretation of Classic Music (Princeton: Princeton University Press, 1991), in particular chap. 2, "Extroversive Semiosis: Topics as Signs," $26-50$; and his figure 2 "The Universe of Topics," 30.

${ }_{27}$ In op. 20, no. 2, second movement, the recitative style is used toward the expression of unanimity as all four players participate in the quasi recitative. 
FIGURE 3. Die Schöpfung: Ein musikalisches Oratorium von Herrn Joseph Haydn übersetzt in Quintetten . . von Herm Anton Wranitzky. (Wien: Artaria E Co., 1800). (C) Bayerische Staatsbibliothek München, Musikabteilung, Signatur: 4 Mus.pr. 37357

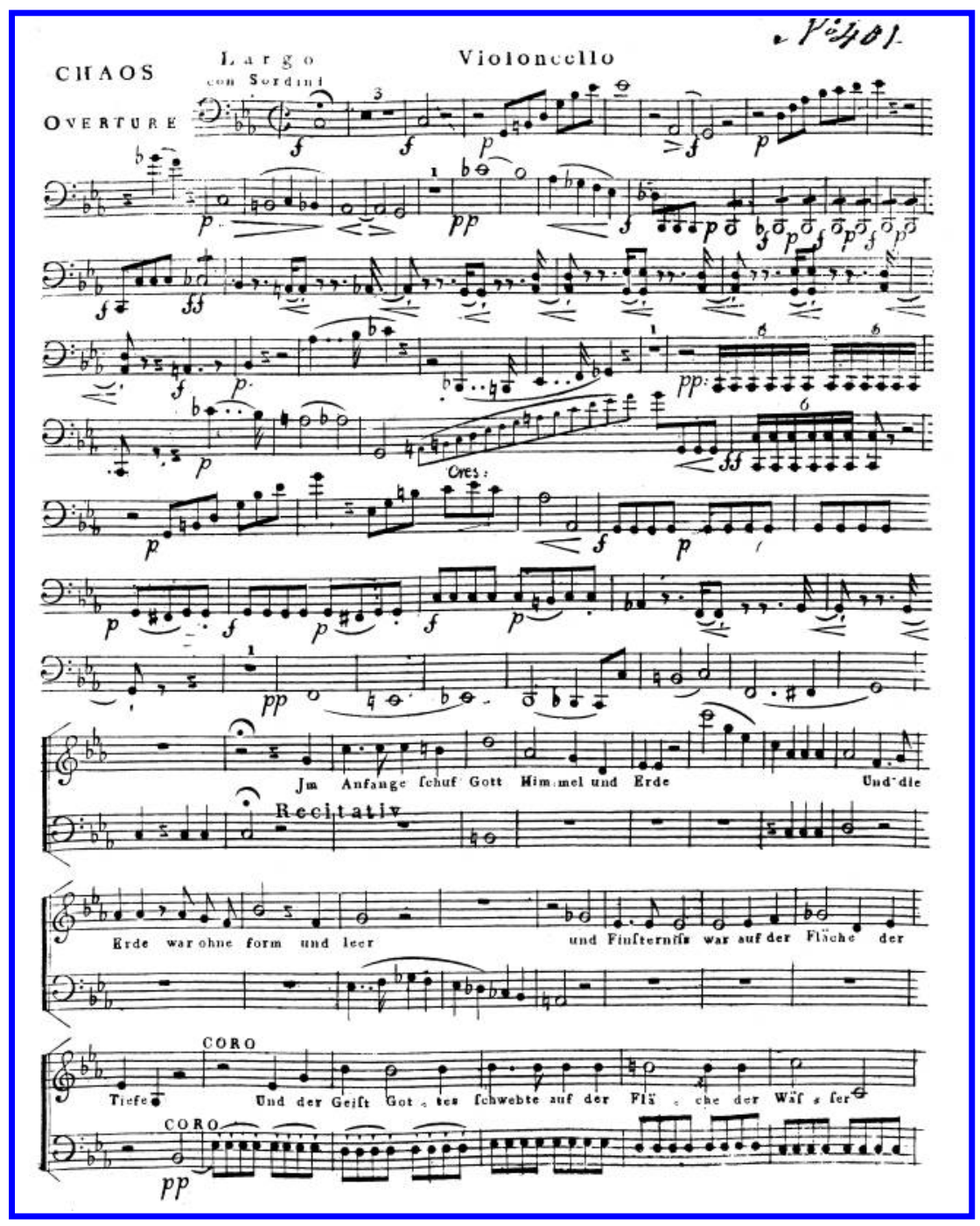

In his quintet arrangement, Wranitzky assigned each recitative to one instrument, thereby turning it into a metaphorical speaker who intones the words without pronouncing their conceptual content (fig. 3 and ex. 1). In keeping with this approach, he avoided direct correlations between voice type and instrument (i.e., there is no mere 
FIGURE 3. (continued)

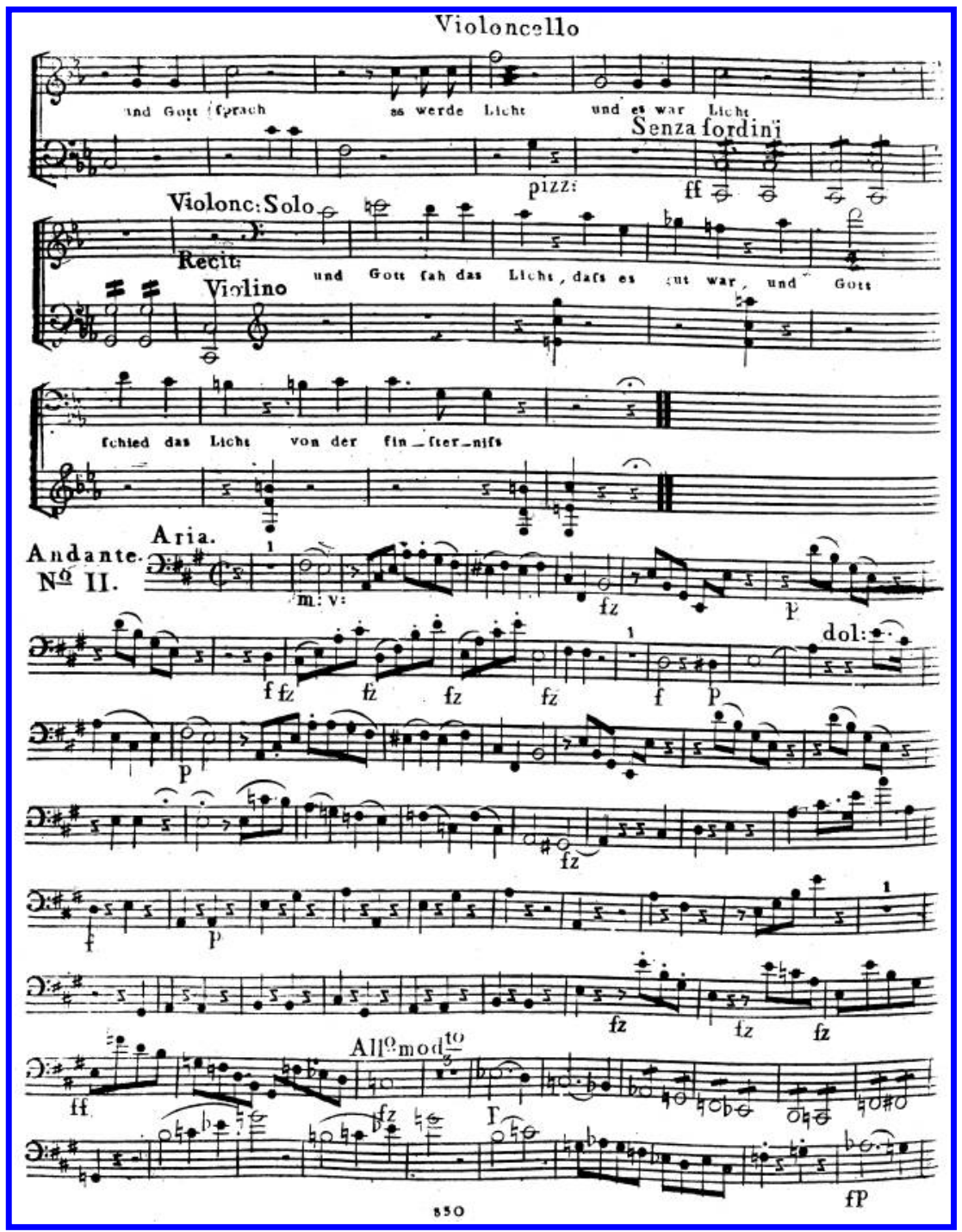

translation of tenor, bass, and soprano into viola, cello, and violin). On the contrary, in the opening recitatives of The Creation, Wranitzky reversed the voice order by giving Raphael's recitative to the violin and Uriel's to the cello. ${ }^{28}$ This is the only recitative in the arrangement to

${ }_{28}$ The result is that Raphael's opening recitative is intoned by the violin one octave above the original, whereas Uriel's recitative remains at the original sounding pitch. The violin continues its recitation by adopting the soprano line of the succeeding choral passage. 
EXAMPle 1. Die Schöpfung: Ein musikalisches Oratorium von Herrn Joseph Haydn übersetzt in Quintetten . . . von Herrn Anton Wranitzky. (Wien: Artaria E Co., 1800). Einleitung, mm. 59-96
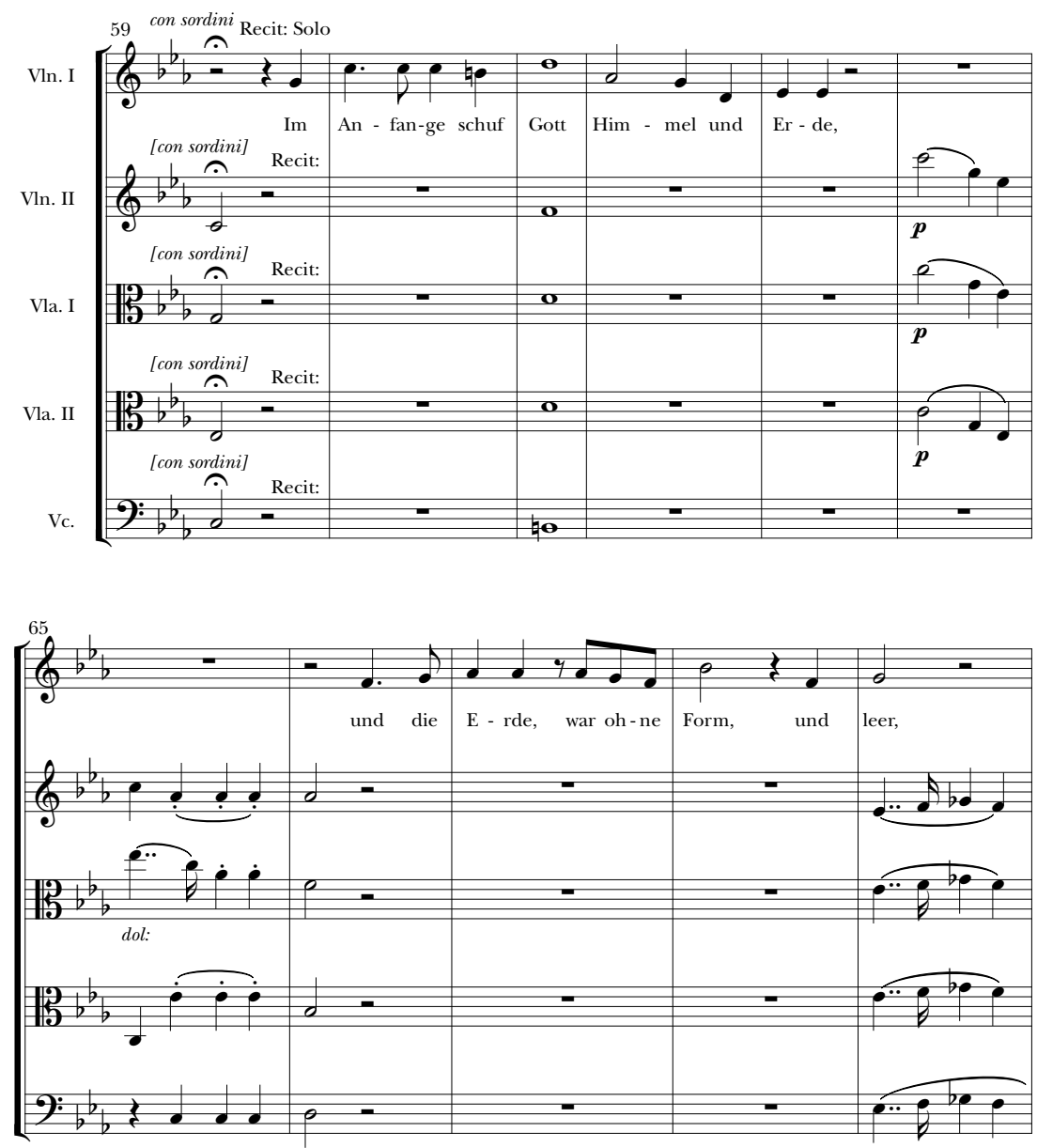

be played by the cello; others are taken by the first viola or first violin. It is noteworthy that Wranitzky had the words of the secco recitatives printed in the parts of the "reciting" player and the accompanying cellist, a feature that could serve as either an aide-mémoire to the performer or a performance aid to assist choices of tone, phrasing, and pacing.

The arias are untexted and identified by short text incipits only, a technique previously employed in the Seven Last Words. Throughout the arias, one instrument is marked "solo," yet the vocal line may in some 
EXAMPLE 1. (continued)
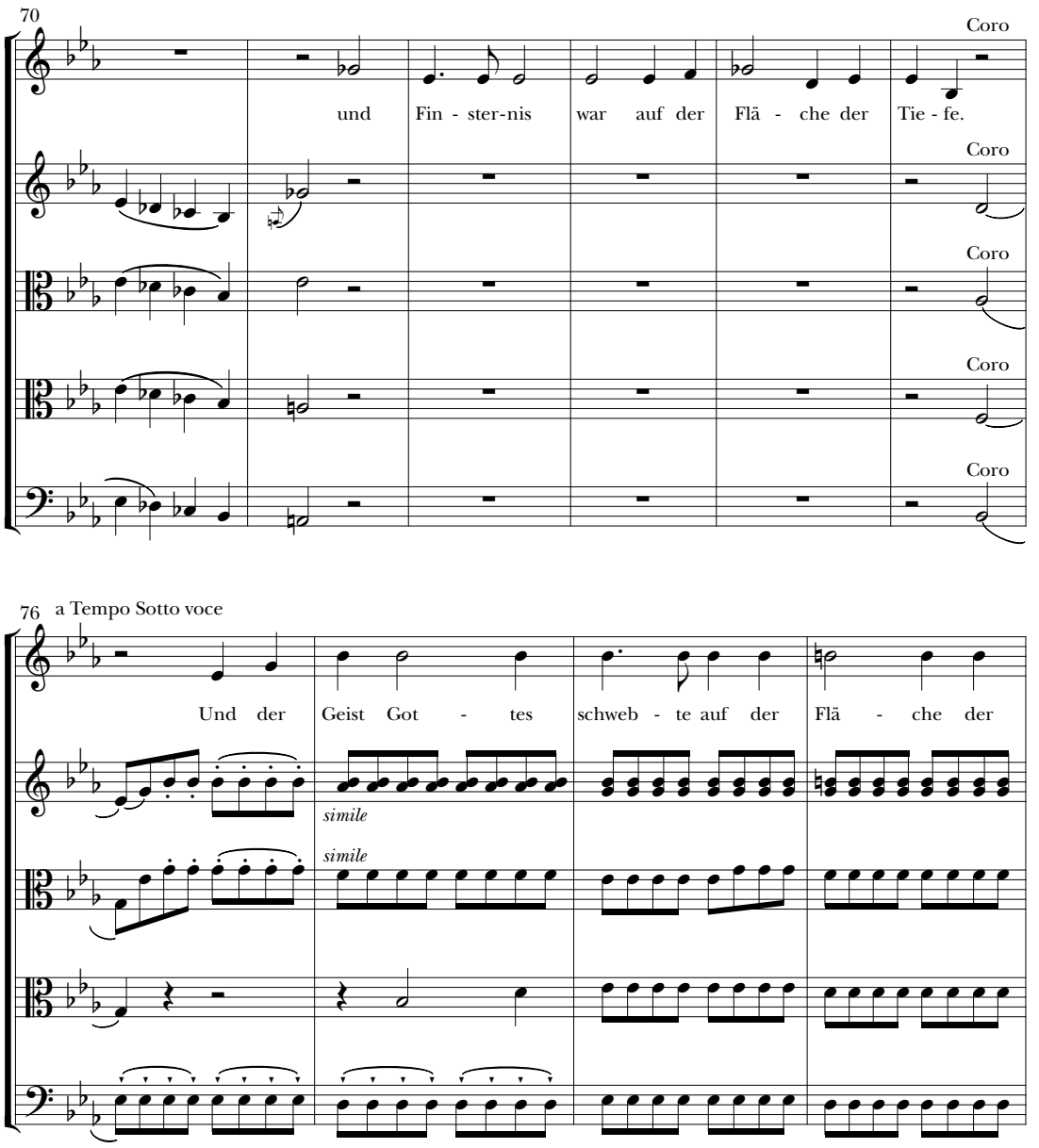

cases be distributed across various parts. Ornaments are added and octave registers changed-interventions that help to transform the quintet into a bona fide instrumental work and to narrow the gap between the arrangement and the chamber music genre, the tone of which it assumes.

By the time of Wranitzky's arrangement, chamber music had accrued a body of compositional theory that combined the more easily accessible galant style, demanded by the amateur market, with the idea of equality among parts. Compositional mastery was a necessary requirement for the composition of chamber music, and of the string quartet in particular, "because these pieces consist of three or four Hauptmelodien, 

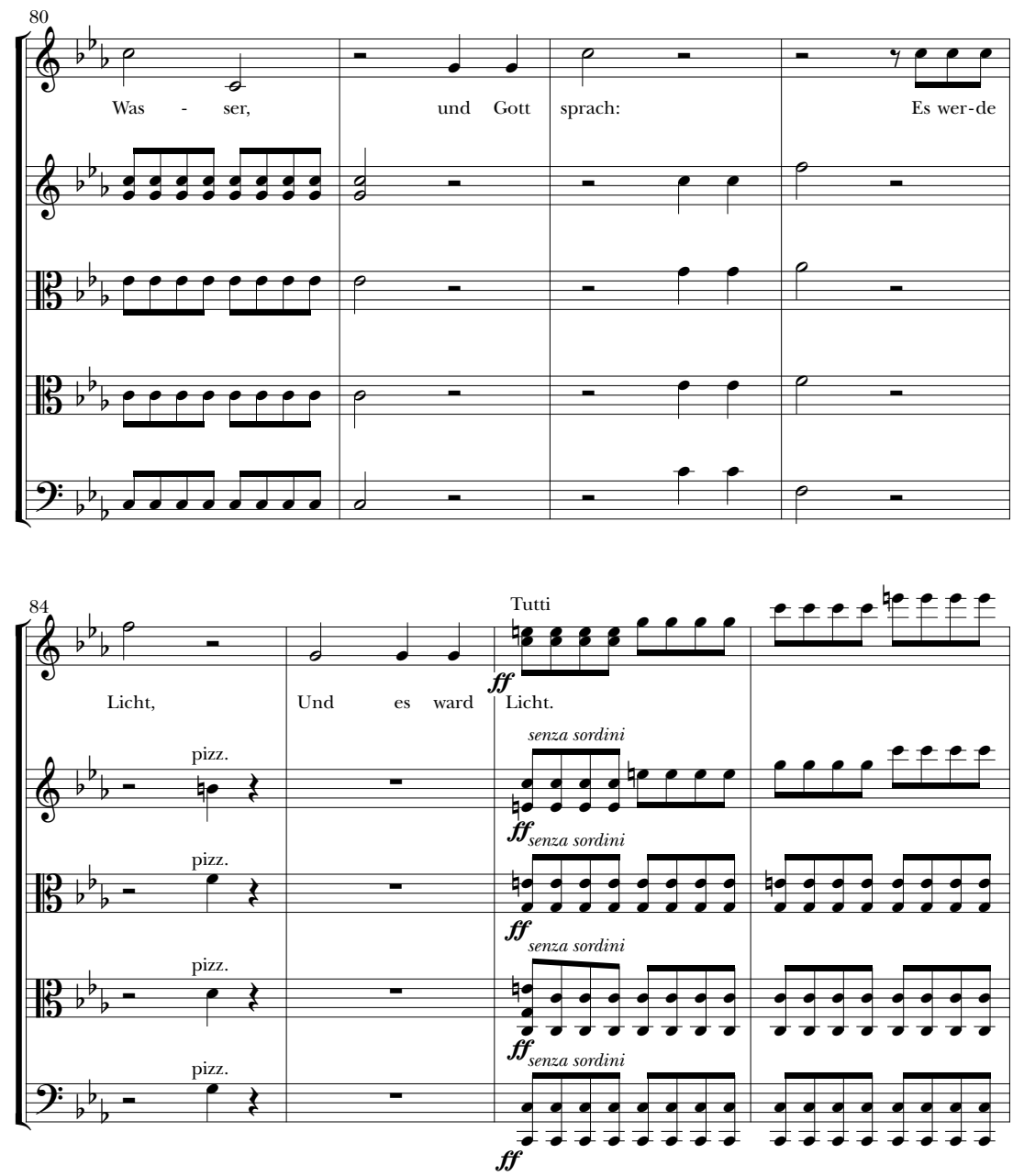

each of which must have its own proper voice-leading without one clouding the other," as Kirnberger explained in the Allgemeine Theorie der schönen Künste. ${ }^{29}$ Sulzer stressed the difficult combination of songlike

29 "Weil in diesen Stücken drey oder vier Hauptmelodien sind, deren jede ihren guten Gesang haben muß, ohne dass eine die andere verdunkele, so ist dieses eine der allerschwersten Arten der Tonstücke, und erfodert einen im Contrapunkt vollkommen geübten Meister." Sulzer, "Quartet; Quatuor," in Allgemeine Theorie der schönen Künste, 3:755-56. Koch explains the same almost verbatim: "Weil aber die modernen Quartetten in der galanten Schreibart gesezt werden, so muß man sich an vier solchen Hauptstimmen begnügen, die wechselweise herrschend sind, und von denen bald diese, bald jene 

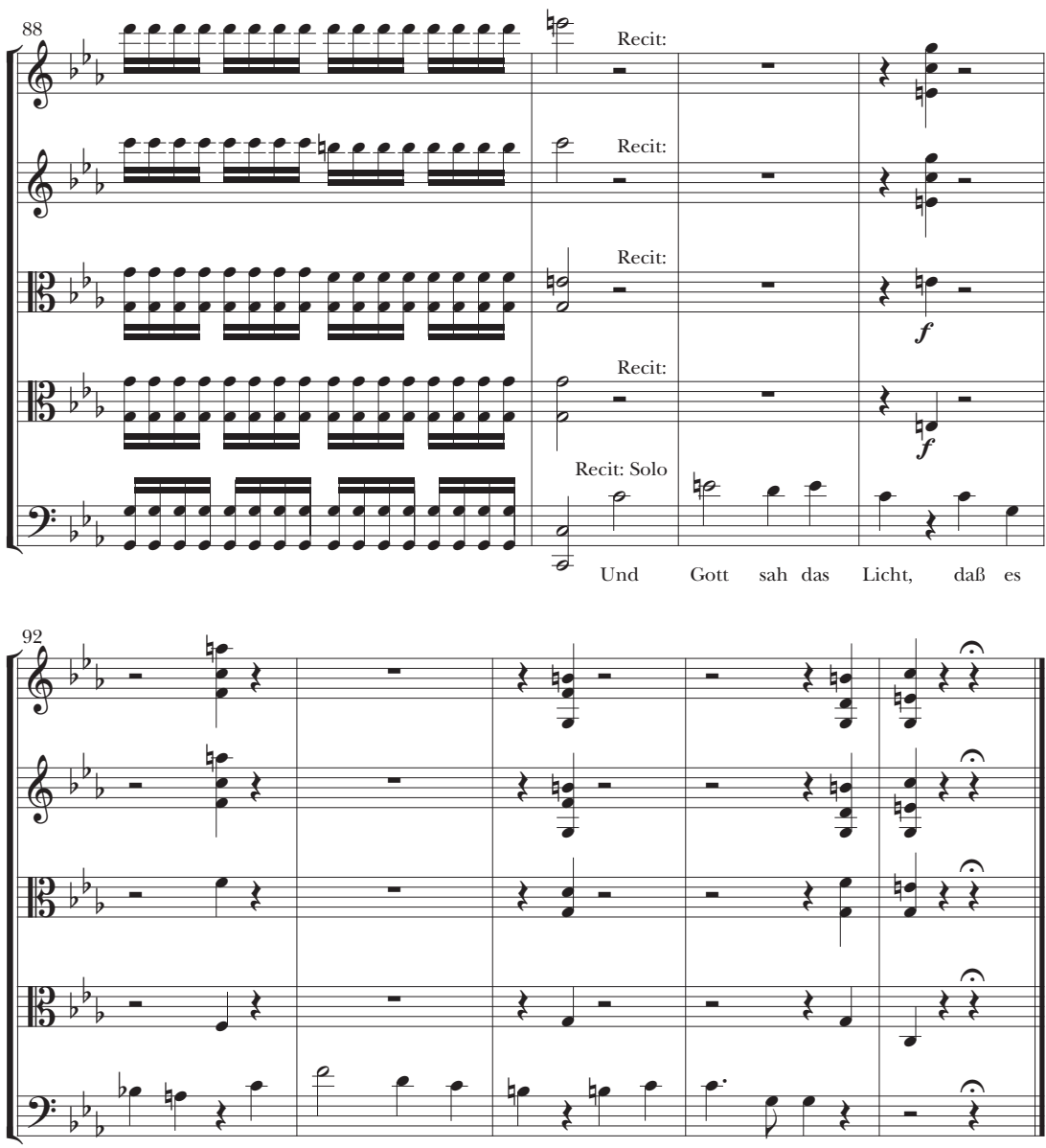

gut war, und Gott schied das Licht von der Fin - ster-nis.

melody with counterpoint, the necessity for equality and imitation, the balance between diversity and unity. Yet what he described as a particular requirement of the string quartet formed the basis for his judgment

den Tonstücken von galantem Stiele gewöhnlichen Baß macht. Während aber sich eine dieser Stimmen mit dem Vortrage der Hauptmelodie beschäftigt, müssen die beyden andern, in zusammen hängenden Melodien, welche den Ausdruck begünstigen, fortgehen, ohne die Hauptmelodie zu verdunkeln. Hieraus siehet man, dass das Quatuor eine der allerschwersten Arten der Tonstücke ist, woran sich nur der völlig ausgebildete, und durch viele Ausarbeitungen erfahrne Tonsetzer wagen darf." Johann Christoph Koch, "Von dem Quatuor," Versuch einer Anleitung zur Composition (Leipzig, 1 793), 3:325. 
on chamber music in general. "Because chamber music is for connoisseurs and lovers of music," he explained, "the pieces can be composed in a more learned and artificial style than those deemed for public consumption; in those everything needs to be simple and cantabile so that everyone can grasp it." $3^{\circ}$ Whereas this passage presents compositional mastery and intricate style as an advantage, Sulzer continued by stressing the absolute necessity of "reiner Satz," "feinerer Ausdruck," and "künstlichere Wendungen" in chamber music, as this type of music gained meaning through its intellectual appeal. ${ }^{11}$

Wranitzky's arrangement shows an awareness of this compositional approach when weaving what was once the vocal line into the instrumental fabric as an equal partner. As such, the arrangement borrows an association of the string quartet and quintet that is more subtle. Theorists' focus on desirable compositional parameters in the quartetvoice leading, the exchange of function from melody to accompaniment, the variety of parities among the voices, the technique of imitation, concord and counterpoint-was inspired by the need to respond to the problem posed by instrumental music void of external function. Their answer shifted the focus from music's appeal to the body as the seat of emotions to the mind as the facilitator of emotions sparked by the recognition of compositional, "artificial" intricacies..$^{2}$ Coupled with neither religious nor moral sentiments evoked by church setting or a libretto's text, the music's physical, emotional effects were linked by theorists to intellectual processes of recognition and learning, and they declared the music to be both an intellectual exercise for the

$3^{0}$ "Da die Cammermusik für Kenner und Liebhaber ist, so können die Stücke gelehrter und künstlicher gesetzt seyn, als die zum öffentlichen Gebrauch bestimmt sind, wo alles mehr einfach und kantabel seyn muß, damit jederman es fasse. . . In der Cammermusik wird man sich des äußerst reinen Satzes, eines feinern Ausdruks und künstlicherer Wendungen bedienen müssen." Kirnberger, "Cammermusik," in Allgemeine Theorie der schönen Künste, 1:441.

$3^{1}$ In subsequent discussions of the quartet, the intellectual element of the genre is expressed in the frequent reference to its conversational topos. Finscher, Studien zur Geschichte des Streichquartetts I, 286-94; see also Tilman Sieber, Das klassische Streichquintett: quellenkundliche und gattungsgeschichtliche Studien (Bern: Francke, 1983); Nicole SchwindtGross, Drama und Diskurs: Zur Beziehung zwischen Satztechnik und motivischem Prozeß am Beispiel der durchbrochenen Arbeit in den Streichquartetten Mozarts und Haydns (Laaber: Laaber, 1989).

$3^{2}$ For an overview of this shift of emotions from body to mind, later articulated as a shift from the heart to the brain, see Fay Bound Alberti, "Emotions in the Early Modern Medical Tradition," in Medicine, Emotion and Disease, I 70o-1950, ed. Fay Bound Alberti (Basingstoke, NY: Palgrave Macmillan, 2006), 1-21; Roy Porter, "Barely Touching: A Social Perspective on Mind and Body," in The Languages of Psyche: Mind and Body in Enlightenment Thought, ed. G. S. Rousseau (Berkeley: University of California Press, 199o), 45-80; Fay Bound Alberti, Matters of the Heart: History, Medicine, and Emotion (Oxford: Oxford University Press, 2010). 
composer and an exercise in recognition and conversation for the dilettante performer. ${ }^{33}$

Arrangements such as Wranitzky's bridged the gap between the "nuanced composition" and performative "mechanical finesse" of instrumental chamber music and the conceptual expression of sentiments. 34 Although they confined the original text's concepts to memory in the case of some players, and to the imagination sparked by the work's title and repute in the case of others, they brought to the fore both the intellectual engagement required to recognize and understand the intricacies of chamber-music making and a recognition of the performing body. The phenomenon of such arrangements indicates that the rise of instrumental music itself was not born of purely aesthetic ideologies. Rather, instrumental music yielded to an increasingly nuanced definition of art's function that moved away from the conceptual dictation of moral values (which the words had served) to a moral education achieved through the inspiration of the individuals' inner senses of taste, morality, and sociability, of their intellect and of their imagination.

\section{Inspiring the Imagination, Stirring Taste: Teaching History and Aesthetics Empirically}

"It is certain that experiences alone present a secure basis and enduring material for speculative knowledge," van Swieten argued in a lecture to the Studienhofkommission in $1791 .{ }^{35} \mathrm{He}$ had assumed the office of President of the Court Commission on Education in $1781,{ }^{36}$

33 In its intellectual appeal, chamber music could aspire to the sublime as well. Whereas early theories of the sublime commonly associated it with an overwhelming, irrational grandeur, Immanuel Kant articulated the distinction between the dynamic and the mathematical sublime, thereby splitting the sublime into a physical and an intellectual force. For their articulation in music, see James Webster, "The Creation, Haydn's Late Vocal Music, and the Musical Sublime," in Haydn and His World, ed. Elaine Sisman (Princeton: Princeton University Press, 1997), 57-102.

34 "So veranlaßten alle diese Umstände, daß die ältern Tonsetzer die Kunstprodukte für die Kammer mehr ausarbeiteten, feiner nuancierten, und mehr mechanische Fertigkeit der Ausführer dabey voraussetzten." Koch, Musikalisches Lexikon, 821.

35 "Gewiß ist, daß Erfahrungen allein sicheren Grund und dauerhafte Materialien für speculative Kenntnisse geben, daß ohne jene die abstrakten Begriffe nichts als unfruchtbare Hirngespinste sind, die den Kopf nur verengen, verschieben und irre machen, dass gleichwie die Naturgeschichte für die Physik und derselben zweige die nöthigen Erfahrungen sammelt, sie die Weltgeschichte mit eben der Sorgfalt aufnimmt und allen übrigen Wissenschaften darbiethet." Van Swieten, Vortrag der Studienhofkommission, 15.8.1791, Allgemeines Verwaltungsarchiv, F.106, 298 ex 1791; quoted in Ernst Wangermann, "Das Bildungsideal Gottfried van Swietens," Conference Proceedings "Gerhard Freiherr van Swieten und seine Zeit," Vienna, 8-10 May, 1972 (Vienna: Verlag Hermann Böhlhaus Nachfl. 1972), 180.

$3^{6}$ Van Swieten was appointed "Präses der Studienhofkommission" in 1781 and held the post until 1791 when he was made to retire. He was also the president of the Austrian Court Library from 1777 to his death in 1803 . 
and in this position, he had proposed a radical restructuring of the education system-including university studies-that answered to the larger enlightened project of raising a politically aware and responsible professional class. ${ }^{37} \mathrm{He}$ devised a system that would educate citizens to understand the moral and social pretexts for their actions, rather than simply teaching codes of behavior and canons of knowledge. ${ }^{38}$ Human beings, van Swieten explained, possess two innate faculties, reason and moral sentiment, both of which need educating. They also possess two inner senses (akin to the outer senses of hearing and seeing): taste and the imagination, through which their education ought to be channeled. Moral behavior, he believed, could be taught not by prescription but by honing the innate faculties of reason and moral sentiment, and by exercising the interaction between them.

In aiming to sharpen the inner faculties, van Swieten's teaching focused on the study of both history and aesthetics. His interest in history might be seen to betray a belief, typical for its time, in the teleological development of humankind toward the present as its pinnacle. ${ }^{39}$ Van Swieten did think that the time was ripe for the development of a newly perfected citizen state, but his vision of the present was more

37 Ernst Wangermann, Aufklärung und staatsbürgerliche Erziehung: Gottfried van Swieten als Reformator des österreichischen Unterrichtswesens $178 I-I 79 I$ (Vienna: Verlag für Geschichte und Politik, 1978), esp. "Die Auseinandersetzung mit dem Programm Josephs II," 19-41. Recent literature on the idea of Bildung during the Josephinian era includes Oszkár Sashegyi, Zensur und Geistesfreiheit unter Joseph II (Budapest: Akadémíai Kiadó, 1958); Ulrich Engelhardt, Bildungsbürgertum, Begriffs-und Dogmengeschichte eines Etiketts (Stuttgart: Klett-Cotta, 1986); Helmut Engelbrecht, Geschichte des Österreichischen Bildungswesens: Von den Anfängen bis in die Zeit des Humanismus (Vienna: Österreichischer Bundesverlag, 1982); and M. v. Benedikt, ed., Verdrängter Humanismus, verzögerte Aufklärung: Österreichische Philosophie zur Zeit der Revolution (Vienna: Turia \& Kant, 1992). Given the diversity of Vienna's population in particular, and of the Austrian empire in general, Joseph II's act of tolerance of 1782 was a fundamental precondition for the nurture of an educated middle class, a political act that translated directly into van Swieten's conceptual focus on values common to all denominations, i.e., matters of productivity and morality.

${ }^{8}{ }^{8}$ It is noteworthy that van Swieten included women in his reforms, as he recognized women's seminal role in the formation of the individual: "Da es bekannt ist, wie lange jedes Kind . . . in den Händen der Mutter bleibt, und wie ganz die erste Bildung und Grundlegung der künftigen Begriffe von denjenigen Eindrücken abhängen, welche die ersten Erzählungen und Unterrichte der Mütter und Kinderwärter immer bei Bauern, Bürgern und adelichen auf das junge Gemüth des Kindes machen . . . so darf es keinen Beweises, wie viel dem Staate daran gelegen seyn muß, auch das weibliche Geschlecht auszubilden, das auf die Erziehung aller Kinder einen so lange dauernden . . . und doch einen so unvermeidlichen Einfluß habe." Gottfried van Swieten, Vortrag der Studienhofkommission, 18.8.1784. Allg. Verwaltungsarchiv, Studienhofkommission, F.63, 154 ex 1784; quoted in Wangermann, "Das Bildungsideal," $176-77$.

39 For general discussions of historiographical understanding in late-eighteenthcentury Germany, see, for example, Georg G. Iggers, Deutsche Geschichtswissenschaft: eine Kritik der traditionellen Geschichtsauffassung von Herder bis zur Gegenwart (Vienna: Böhlau, 1997); and Tibor Kneif, "Forkel und die Geschichtsphilosophie des ausgehenden 18. Jahrhunderts," Die Musikforschung 16 (1963): 224-37. 
realistic: around him he witnessed not an educated society but solely the potential for one. History, therefore, became the simultaneous "study of all times and all peoples." Rather than presenting a narrative, van Swieten understood history as "the study of humanity, a school of life, of wisdom and of moral values." 40 He treated the subject as neither chronicle nor teleological process, but rather as a quasi-mythological story-collection that served the purpose of providing models for the interaction of people and events. ${ }^{41}$ If classical mythology had served this function thanks to its unfathomable remoteness, van Swieten was one of the first to exploit the more recent past in this way.

In Vienna he was the foremost advocate of models, at once historical and aesthetic, that were but sixty years old: the compositions of $\mathrm{J}$. S. Bach and G. F. Handel were for him "classics" that he equated in stature and significance with classical literature. ${ }^{42}$ At his salons, informal gatherings held every Sunday at his rooms in the Imperial Library, "nothing is played but Handel and Bach." 43 By way of introduction to this ancient, unfamiliar repertoire, van Swieten had his Viennese friends sing Handel's oratorios accompanied on the piano while being chided by Mozart for any mistakes they made. ${ }^{44} \mathrm{He}$ commissioned Mozart and other regular attendees to prepare transcriptions of Bach's keyboard fugues for string trio and string quartet so as to play them together in these new guises. What had once been an exercise in Erbauung for the individual through solitary concentration on the object's intricacies became an exercise in collaboration. (Bach's fugues in particular were entirely separated from their original performance context and practice, the better to serve as material for the ideologies of van Swieten's times.)

$4^{\circ}$ "Die Geschichte muß sich Ueber alle Zeiten, Ueber alle Völker erstrecken, und wird hier nicht als eine blosse Sammlung der Weltbegebenheiten, . . . sondern als die Gefährtin aller Wissenschaften, als ein Studium der Menschheit, eine Schule des Lebens, der Klugheit, und der Sitten angesehen; sie soll . . . zum hohen Rang des Nachdenkens und der Weisheit hinaufsteigen." Gottfried van Swieten, Vortrag der Studienhofkommission; quoted in Wangermann, "Das Bildungsideal," 178.

$4^{1}$ Van Swieten explains his educational system based on three pillars in his Entwurf für das philosophische Lehrfach, Akten der Studienhofkommission, F.13, 152, 1784. He suggests the study of "Allgemeine Naturgeschichte" as a course in methods, whereas history and aesthetics provided the study of models of experience. See also Wangermann, Aufklärung und staatsbürgerliche Erziehung, 68-70.

$4^{2}$ Handel had gradually acquired the status of a musical "classic," and his oratorios were seminal to this reputation. See Suzanne Aspden, "'Fam'd Handel Breathing, tho' Transformed to Stone': The Composer as Monument," Journal of the American Musicological Society 55 (2002): 39-90; and Claudia L. Johnson, "Giant Handel' and the Musical Sublime," Eighteenth-Century Studies 19 (1986): $5^{1} 5^{-33}$.

43 W. A. Mozart to his father, April 10, 1782, The Letters of Mozart and His Family, trans. and ed. Emily Anderson, 3rd ed. (London: Macmillan Press, 1985), 8 oo.

44 Joseph Weigl, Autobiographie, Vienna Nationalbibliothek, MS.S.m.3347. 
Understanding history as a series of ahistorical models, van Swieten continually conflated history and aesthetics in his teaching system, for he regarded them as two tools that served the same end. The study of history became the study of models of experience, not of facts or value judgments in themselves. Similarly, he explained that the study of aesthetics addressed man's inner feelings and aided the development of a vivid sensation of the true and the good by enabling individuals to experience both for themselves. Both the historical and the aesthetic, then, worked to inspire reaction and experience in its recipients. This in turn informed individuals' reactions to their own experiences.

For this process to work, the aesthetic models-like the historic models-had to be divorced from current practice, because in current practice "having taste" had become tantamount to a set of social behaviors; ${ }^{45}$ in daily artistic practice, taste had ceased to be recognized as an inner sense (the companion of reason and moral sentiment in the triad of inner senses) and had become instead a means of judging. Van Swieten criticized his contemporaries for uncritically adopting given ideas of beauty instead of training and exercising their inner faculty of taste to recognize the beautiful. He sought to return to the idea of taste as the inner sense that could receive the beautiful, stir the imagination, and act on reason and moral sentiment. Thus he removed his aesthetic models from current practice and instead sought them in the past, fashioning new works such as The Creation in the molds of archaic, unfamiliar idioms.

His instructions for the teaching of both history and aesthetics illustrate the significant change van Swieten wished to bring to educational policies. His system heralded the abandonment of dogmatic teaching styles in favor of a school of empirical learning, which his more conservative opponents could only see as dangerous. In his defense he declared that "without experiences all those abstract concepts are nothing but fruitless fantasies, which only narrow the mind, throw it off kilter, leave it demented." ${ }^{46}$ Knowledge and understanding, according to van Swieten, resulted from the unique combination of sensation and reason

45 The word "taste" throughout the eighteenth century was used first to describe qualities inherent in objects of beauty or art, second, as a set of social behaviors, and finally as an innate human faculty. See A. Aronson, "The Anatomy of Taste," Modern Language Notes 61 (1946): 228-36; Franz Schümmer, "Die Entwicklung des Geschmacksbegriffs in der Philosophie des Achtzehnten und Neunzehnten Jahrhunderts," Archiv für Begriffsgechichte 1 (1955): 120-41; Robert W. Jones, Gender and the Formation of Taste in Eighteenth-Century Britain (Cambridge: Cambridge University Press, 1998); Andrew Hemingway, "The Sociology of Taste in the Scottish Enlightenment," Oxford Art Journal 12, no. 2 (1989): 3-35; Claudia Kaiser, "Geschmack" als Basis der Verständigung: Chr. F. Gellerts Brieftheorie (Frankfurt am Main: Peter Lang, 1996), esp, 16-36 and 111-51; and HansJürgen Gabler, Geschmack und Gesellschaft (Frankfurt am Main: Peter Lang, 1982).

$4^{6}$ Van Swieten, Vortrag der Studienhofkommission, 15.8 .1791$. 
that defines a human experience. Harking back to the ancient Greeks who did not distinguish verbally between the good, the true, and the beautiful, van Swieten considered the true and the good to be encapsulated in the beautiful. Yet in its beautiful form, the true and the good addressed not human reason but each individual's inner sensations.

As beauty was seen to affect the human senses and the human heart directly without recourse to reason, the study of art rose in significance by complementing the study of facts and models with the cultivation of inner sensibility. A national teaching system, therefore, had to include the teaching of aesthetics. Art was a matter of national concern.

$$
* * *
$$

Van Swieten practiced what he preached. His Sunday salons served him to explore repertoire from his extensive private collection together with select members of society. Here, Handel's oratorios were first played in reduced versions; later, in 1786 , van Swieten joined some of Vienna's wealthy noblemen in founding the Gesellschaft der Associierten Cavaliere with the intention to perform these oratorios publicly using the same grand forces that their staging customarily involved in England by then. ${ }^{47}$ Yet in his involvement in the arts and his advocacy of grand artistic endeavors, van Swieten was more than an impresario. In devising the libretto for The Creation, he aimed at creating a new musical "classic" modeled on the "ancient" oratorio tradition, tapping into the cultural imagination aroused by Handel and exploiting Haydn's fame as a composer who was internationally renowned less for his operas than for his instrumental music. This reputation would ensure that in the mind of the recipients the work was instantly leveled at something beyond its narrative content.

Indeed, reviewers repeatedly stressed that The Creation's forceful effect on the recipient's imagination lay beyond text and language. ${ }^{48}$ Their explanation of this power presents an intermediate step between the early eighteenth-century desire for the cognitive content of words and the Romantic abandonment of conceptuality in favor of music as

47 Edward Olleson, "Gottfried van Swieten, Patron of Haydn and Mozart," Proceedings of the Royal Music Association 89 (1962/63): 63-74; Teresa M. Neff, Baron van Swieten and Late Eighteenth-Century Viennese Musical Culture (PhD diss., Boston University, 1998); Georg Heilingsetzer, "Politik, Gesellschaft und Kultur im Jahre 1798. Die historischen Rahmenbedingungen von 'Haydns Schöpfung'," Wiener Geschichtsblätter 54 (1999): 101-25; Otto Biba, "Gottfried van Swieten," Europas Musikgeschichte: Grenzen und Offnungen: Vorträge des Europäischen Musikfestes Stuttgart 1993, ed. Ulrich Prinz (Kassel: Bärenreiter, 1997), $120-37$.

$4^{8}$ Correspondence, Jan. 8, 1801, Allgemeine musikalische Zeitung 3 (1801): 289-96. quoted and trans. in Landon, Haydn: The Years of "The Creation," 588 . see also note 25. 
the artistic companion to man's unstable soul. ${ }^{49}$ Reviews of The Creation dealt in images conjured by the instruments' impression on man's soul, and they described the music's power as stemming from its "suggestions to our imagination." As the correspondent for the Allgemeine musikalische Zeitung observed in 1801: "From [a gigantic unison] single notes come forth, which in turn spawn others." He explained the music's appeal to the listener's imagination by likening it to natural images such as "great floods" that "gradually seek their proper beds," "a star [which] moves in its path," and "swimming forces [that] approach land. " $\mathrm{He}$ also drew on abstract images, describing the music's unfolding in front of the listener's inner eye as "huge forces grating against each other" only to "dissolve harmonically and then sink back into darkness." 50

Although the dynamism of these descriptions heralds the expressive power of music per se, texted or untexted, the relationship they suggest to man's soul is not yet the congruency that the Romantics would claim for instrumental music scarcely a decade later. Instead, the music communicates with the soul; it speaks to our inner sentiment but is not congruent with it. Art, then, did not express inner sentiments so much as it resonated with them by stirring the inner senses of taste and the imagination.

\section{Art, Education, and Adaptability}

Van Swieten promoted a pragmatic interpretation of his aesthetic paradigm: his educational reform plans were novel and audacious, because his belief in an innate morality allowed him to free education from strictures of censorship that had traditionally dictated the choice of particular texts in particular forms. In a final bid to justify the positions taken in his educational reforms at large, van Swieten focused on the education of taste in his lecture "Ueber die Bildung des Geschmacks

49 Compare note 10 on the changing aesthetic of instrumental music. For a more general discussion of the shift from the eighteenth-century aesthetic to the early Romantics, see M. H. Abrams, The Mirror and the Lamp: Romantic Theory and the Critical Tradition (Oxford: Oxford University Press, 1953).

$5^{\circ}$ "There are spun forth forms and figures, without line and order, that disappear only to appear again in different guise. Movement begins. Huge forces grate against each other and begin to gestate, and occasionally, as if fortuitously, they dissolve harmonically and then sink back into darkness. A swirling and twisting of unknown forces, which gradually separate themselves and leave clear breaks, announce that order is near. Each flood gradually seeks its proper bed, not without forcing. Here a star moves in its path, there another one. The swimming forces approach land. Similar forms attract each other and embrace. It is night. And God spoke: Let there be light! And there was light!" Allgemeine musikalische Zeitung 3 (1801): 289-96; quoted and trans. in Landon, Haydn: The Years of "The Creation," 587 . 
durch Lesung klassischer Schriften der Alten."51 After rehearsing the notions of inner sentiments, he condensed his educational ideals to answer two pragmatic questions: what material was suitable for the education of taste, and how should that material be approached? ${ }^{52}$ The answer to the first question, as we have seen, involved the use of historical and aesthetic models that were removed from both ingrained habits of society and preconceived judgments. A musical language such as Bach's and Handel's served his purpose well because its archaism stood in stark contrast to the galant, melody-based music that typified Viennese chamber music in the 178 os and gos.

Van Swieten answered the question "How should they be read?" by suggesting an approach that would explore the artwork's disposition in terms of "language, the beautiful sciences, sentiments, customs and philosophies in an engaging lesson." He continued that this must be done via "pleasurable repetition." ${ }^{33}$ Indeed, repetition was essential in order to explore varying perspectives, for the classical texts were both models and material to be explored from different viewpoints through multiple readings that could potentially yield different results and different levels of meaning.

For music to be repeated often for different audiences, and by different performers, it had to be adaptable. As we have seen, a work like Haydn's Creation was adapted for a variety of performances and for publication and was thus brought to audiences in multiple guises. Thus it is difficult to uphold any qualitative distinction between original and arrangement with respect to the music's function, i.e., its fusion of entertainment and education. In fact, the close semblance between some of the smaller performances and, say, the quintet arrangement is exemplified by a diary entry from the Viennese Count Carl Zinzendorf. On April 4, 180o, he recorded his attendance at a "concert at Count Fries" during which he enjoyed The Creation more than ever before. Credit for

$5^{1}$ Gottfried van Swieten, "Ueber die Bildung des Geschmacks durch Lesung klassischer Schriften der Alten," Wien-Nationalbibliothek-Handschriftensammlung NB HSS

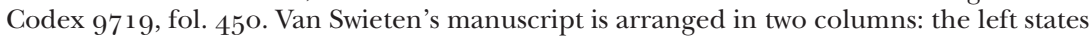
a series of sixteen questions; the right gives the answers. Questions 1 to 10 in part borrow material verbatim from Sulzer's article "Geschmack" in the Allgemeine Theorie der schönen Künste; the final six questions, however, introduce entirely new material. See Sulzer, "Geschmack," in Allgemeine Theorie, 4:371-73.

$5^{2}$ The questions I refer to here are presented in the final part of the script: "Sind die klassischen Schriften der Alten dazu tauglich? Wie sind sie es? Warum sind sie es? Wie sollen sie mit der Jugend gelesen werden? Was ist darbey zu beobachten? Was zu vermeiden?" Van Swieten, "Ueber die Bildung des Geschmacks," fol. 45 ov.

53 "So dass sie in Absicht auf sprache auf Anleitung zu den schönen wissenschaften auf Gefühle und Gebräuche, auf philosophie zu einem unterhaltenden Unterricht und zur angenehmen wiederholung dienen." Van Swieten, "Ueber die Bildung des Geschmacks." 
this might have been owing to the singers, of whom he reported that "Madame Schoenfeld sang like an angel, Reitmeyer quite well, and the Prince Lobkowitz-despite his lack of timbre-with great expression." With a hint of surprise he noted that this pleasing performance was achieved by "only nine instruments and especially not a single wind instrument." 54 Although the performance involved singers, it clearly was an unusually small affair.

Similarly, the Swedish diplomat Fredrik Samuel Silverstolpe, an ardent admirer and connoisseur of Haydn's music, reported another version or "performance" of The Creation:

I want to make a small present to all my brothers, and I hope you will be pleased with it. It is The Creation arranged by Wranitzky as sextets. It is quite effective in this version and much better than the quintets, in which form the work has already been printed, arranged by the same master. I would advise you not to buy the quintets if they come to Stockholm later, for the work loses too much if you hear it like that the first time. ... The flauto traverso makes an effect that is indispensable to the whole. ${ }^{55}$

The flute is the extra ingredient that elevates the sextet arrangement from one best suited for van Swieten's "pleasurable repetition" to a status where it becomes viable as the first experience of the work. Here, the criterion for an instantiation representing the "work" is drawn not in terms of genre and performing forces but in terms of a timbral effect that adds a layer of reminiscence to Haydn's effective use of woodwind instruments. The addition of the flute also rendered the arrangement closer to the original by undermining an otherwise strong association with string chamber-music sonority. In effect, it softened the shift in genre.

Music, possibly more than any other art form, was adaptable to different audiences; through its instrumentation it was capable of conjuring strong associations and reminiscences. But what the arrangements offered over and above the various orchestral adaptations was the

54 "Au concert chez Fries. Jamais la musique de la Création ne m'a plû autant quoiqu'il n'y avoit que neuf instrumens, et surtout point d'instrumens a vent. Me de Schoenfeld chanta comme un Ange, Reitmeyer très bien, et le Pce Lobkowitz malgré son peu de timbre avec expression." Quoted in Edward Olleson, "Haydn in the Diaries of Count Karl von Zinzendorf," Haydn Yearbook 2 (1963-64): 45-63. In Performing Haydn's "The Creation," Brown mistakenly lists nine wind players as the performers on April 4, 1800 . Landon notes the same diary entry and conjectures that the performance at Fries's palace used "one of Wranitzky's arrangements, i.e. for string quintet or sextet, the former with piano and the latter with flute" to accompany the vocal parts. See Landon, The Years of "The Creation," 546 . This assumption remains speculative.

55 C.-G. Stellan Mörner, Johan Wikmanson und die Brüder Silverstolpe (Stockholm: Ivar Haeggströms Boktryckeri, 1952), 350; quoted and trans. in Landon, Haydn: The Years of "The Creation," 544 . 
unrestricted repetition of repertoire by anyone, whether professional or amateur, who owned the parts.

Significantly, the salon became a forum for individuals to repeat and experience music frequently in guises other than those associated with public performance. Here, composers customarily presented their latest compositions prior to a public performance by singing and playing at the keyboard. Trial runs of operas with few participants were as common as the post-public performances that relived musical experiences through the singing of select arias and the small-scale performance of entire works. In short, the arrangement of music for rendition in the salon served several purposes: preview and review, premiere and repetition, entertainment and education.

\section{Active Engagement and the Notion of Physicality}

Van Swieten's answer to the second pragmatic question "How should they be read?" entailed another demand: the individual had to become actively involved with the art to ensure a valuable learning process and grant lasting effect. The encouragement he gave his friends to arrange Bach's fugues for string trio and string quartet transferred this demand into practice: whereas the act of arranging forced the arranger into an intensive study of the work, the subsequent sociable experience of playing the fugues with two or three companions added another level of integration and interaction as each individual embodied one voice in the complex fugal web, vying for attention with the other voices but also cooperating with them. The compositional structure was made literal, and the players experienced the workings of a fugal structure from the inside. ${ }^{56}$

Van Swieten advocated the idea of active engagement equally in his revised university system. Considering all existing texts unsuitable for his new program of education, he proposed the temporary abolition of all set texts in order to encourage consideration, deliberation, and reflection as the basis for understanding. He promoted free lecturing followed by reactions and questions from the floor, after which the students would write their own memoranda. ${ }^{57}$ "The student will affirm

$5^{6}$ For a contemporary comment on the special, enlightened value of fugues, see Georg Joseph Vogler, System für den Fugenbau (Offenbach, 1811); quoted and trans. in Neal Zaslaw, Mozart's Symphonies: Context, Performance Practice, Reception (Oxford: Clarendon Press, 1989), 544: "The fugue is a conversation among a multitude of singers. . . . The fugue is thus a musical artwork where no one accompanies, no one submits, where nobody plays a secondary role, but each a principal part."

57 Van Swieten planned to shift the prescription of teaching texts from the government committee to the university professors, ultimately with a view to approving new texts as guidelines for future teaching. See also Wangermann, Aufklärung und staatsbürgerliche Erziehung, 82 . 
his desire for knowledge and his diligence through recording the contents of his lessons subsequently. Here he can probe his own faculties of understanding; it impresses the lesson on to him because it demands a variety of his faculties at once." ${ }^{58}$ Van Swieten considered the individual creation of texts and the crucially important engagement with the material at hand as essential, because the point of education-especially at the level of the intellectual elite-was to activate and inspire critical thinking, investigation, and negotiation.

His system relied on the experience of learning, which he defined as the combination of sensual perception and rational mediation. ${ }^{59}$ True understanding could only be the result of a mediated sensation, never of reason alone. Teaching methods had to involve the student's action to be inductive; they fulfilled their goal to empower individuals only if they aided the awareness of both the individual's sensations and reason. ${ }^{60}$

Simply receiving the works, then, was not enough; meaning lay in action, not in stasis. Van Swieten's ideals were widely practiced in his Viennese circles as myriad art forms were arranged and adapted so as to turn them from acts of spectation to an activity. Frequently, the adapted arts shared a common denominator: designed to actively engage with art's emotive language, each one helped the individual to translate sensations expressed or encoded in a particular play, painting, or myth into physical movement. Domestic theater performance, for instance, was a favorite of the Viennese nobility; Count Karl Zinzendorf recorded numerous performances of Comédie de Société in which members of the nobility entertained themselves by acting out pieces that had recently been in the repertoire of the national theater. ${ }^{61}$ Caroline Pichler, daughter of the illustrious salonier Hofrath Greiner, gave sumptuous and

$5^{8}$ "Das Aufzeichnen des Unterrichts in und außer dem Hörsale ist jederzeit bey dem Schüler das sicherste Merkmal seiner Wissbegierde und seines Fleißes, der beste Probestein von der Eigenschaft und der Anwendung seiner Geisteskräfte, das wirksamste Mittel, den Eindruck der Lehre durch mehrere Sinnen und mit gewechselter Aufmerksamkeit deutlich und dauerhaft zu machen." Van Swieten, Vortrag van Swietens, 1791, quoted in Wangermann, Aufklärung und staatsbürgerliche Erziehung, 82 .

59 "Was ist darbey zu beobachten? Etwas zu vermeiden?-Dass man bei den Vorlesungen die Gestalt einer akademischen fragen unterredung gebe. So würde also sehr gehasst sey, \wenn man dieser Übung das unangemessene einer bloß grammatikalischen Lektion gäbe oder die trockene immer scholastische Untersuchung, oder sie durch ausschweifungen und Ausformung unnützer Gelehrsamkeit Ueberlade und die Jugend verdrießlich mache." Van Swieten, "Ueber die Bildung des Geschmacks."

6o "Die erste Hand muß an die Bildung des Herzens und des Verstandes gelegt sein." Gottfried van Swieten, Entwurf für das philosophische Lehrfach, 1784, quoted in Wangermann, Aufklärung und staatsbürgerliche Erziehung, 69.

61 Dorothea Link, "Vienna's Private Theatrical and Musical Life, $1783-92$, as Reported by Count Karl Zinzendorf," Journal of the Royal Musical Association 122 (1997): $205-57$. 
detailed descriptions of the interaction with art that took place in his salon. Concerned with the spiritual and social education of a person, he had promoted the discussion of literature, regular private theater performances, and music-making. ${ }^{62}$ Comédies de Société were played regularly; every Monday the younger generation performed famous scenes from plays or mythology as charades. "Geschichten spielen"-a game that had been initiated at Ignaz von Born's salon-was another favorite activity in which scenes from famous plays were presented in pantomime. ${ }^{6}$ Whereas this guessing game combined both physical display and intellectual recognition, the popular tableaux vivants focused on the physical side of the experience. In effect, they dissolved the textuality of painting into the experience of performance by re-creating famous paintings live: each person would assume the role and pose of one of the (mostly mythological) figures in a chosen painting. Not only did the game rely on knowledge of the paintings-indicating how the artistic "canon" could foster a strong sense of community-but it strengthened the knowledge and impression of paintings of historical and literary episodes in the minds of the enactors. Both artwork and its emotive expression were reinforced through the sensual experience of its embodiment. ${ }^{6} 4$

62 Caroline Pichler, Denkwürdigkeiten aus meinem Leben, 4 vols. (Vienna: Druck und Verlag von A. Pichler's sel. Witwe, 1844); James van Horn Melton, "School, Stage, Salon: Musical Cultures in Haydn's Vienna," in Haydn and the Performance of Rhetoric, ed. Tom Beghin and Sander M. Goldberg (Chicago: University of Chicago Press, 2007), 80-108, esp. 104; Roswitha Strommer, "Wiener literarische Salons zur Zeit Joseph Haydns," in Joseph Haydn und die Literature seiner Zeit, ed. Herbert Zeman (Eisenstadt: Selbstverlag des Instituts für österreichische Kulturgeschichte, 1976), 97-121.

63 Pichler, Denkwürdigkeiten aus meinem Leben, 171 .

64 August Langens, "Attitüde und Tableau in der Goethezeit," Jahrbuch der Schillergesellschaft 12 (1968): 194-258; Sybille Demmer, Form und Geschichte des Monodramas (Cologne: Böhlau, 1982), esp. 38-46; Kirsten Gram Holmström, Monodrama, Attitudes, Tableaux Vivants : Studies on Some Trends of Theatrical Fashion I770-I8I5 (Stockholm: Almquist \& Wiksell, 1967). Similarly, Attitüden turned the static depiction of emotions in mythological painting into movement. The assorted emotions depicted in the painting simultaneously in the different characters were acted out in a chronological series of gestures. Stripped of external motivation, emotions were communicated as pure unsolicited states through physical poses. Lady Emma Hamilton turned this into a performance art; the power of her performance rested not on a static-pictorial display but on the visualization of an authentically experienced sensuous act. This technique bore close resemblance to the acting theories that underpinned ballet-pantomime. See Ulrike Ittershagen, Lady Hamiltons Attitüden (Mainz: P. von Zaabern, 1999), 14. The physicality of Attitüden and tableaux vivants is discussed in Dagmar v. Hoff and Helga Meise, "Tableaux Vivants-Die Kunst und Kulturform der Attitüden und lebenden Bilder," in Weiblichkeit und Tod in der Literatur, ed. Renate Berger and Inge Stephan (Cologne: Böhlau, 1987), 69-86; D. v. Hoff, Dramen des Weiblichen-Deutsche Dramatikerinnen um I 8 oo (Opladen: Westdeutscher Verlag, 1989). For similarities in ballet-pantomime as staged in Vienna, see Paul Frederick Marks, "The Reform of Subject and Style in Ballet-Pantomime at Vienna between 1740-1767," in Woman in the I8th Century, and Other Essays, ed. Paul Fritz and Richard Everett Morton (Toronto: Hakkert, 1976), 141-85; see also Alexandre Dratwicki, "Haydn et Mozart 
The grandeur and significance of an "original," then, could be enhanced in the individual's imagination if received through a variety of senses. Playing The Creation rather than listening to it, for instance, could add value to the individual's experience of the work and perhaps prove essential to its effectiveness. By decoding the musical texture into its component parts, and by ascribing each part to one player, each experienced an analytical exegesis of the fully scored work while at the same time staying connected to an emotional response (or at the very least the recollection thereof) and to a physical act. The individual might, for instance, have enacted by turns one of the aforementioned $A m Z$ correspondent's "single notes" that "come forth (and) in turn spawn others," then "a figure, without line and order" before eventually joining forces with four colleagues to "dissolve harmonically and then sink back into darkness." Rather than experiencing the whole of the "huge forces grating against each other" from the outside, the player became an actual part in the emergence of the musical structure. ${ }^{65}$ Playing a musical setting of a grand subject such as The Creation allowed the individual not only to experience its effects but to reenact its creative processes, thereby grasping the emotions it expressed and informing them with reason.

The idea that emotional sensations were tied directly to mechanical actions was in fact the aspect of untexted music that troubled theorists like Sulzer and Kirnberger. In his article "Musik" for the Allgemeine Theorie, the latter conceded that "music forces itself upon us because it touches our nerves; it speaks because it awakens certain passions in us," a concession that acknowledged music's powerful effect on the individual's physiology and sensuality without the mediation of reason. ${ }^{66}$ This very effectiveness contributed to the suspicions voiced against instrumental music, because "one would see it in no other art, that it seizes

dansés à l'Opéra de Paris: Le transfert émotionnel entre chorégraphie et musique dans le ballet-pantomime classique (1776-1815)," in De la rhétorique des passions à l'expression du sentiment, ed. Frédéric Dassas and Barthélémy Jobert (Paris: Cité de la Musique, 2003), 78-87.

65 Allgemeine musikalische Zeitung 3 (1801): 289-96; quoted and trans. in Robbins Landon, Haydn: The Years of "The Creation," $5^{87}$. Compare n. 39.

66 "Musik dringet ein, weil sie die Nerven angreift; und sie spricht, weil sie bestimmte Empfindungen erweken kann." Sulzer, "Musik," in Allgemeine Theorie, 3:434. Kirnberger illustrated his claim that music is an actual physical force that effects not only the inner movement of our passions but also the movement of our bodies in dance. In a dance the figures must be adjusted to the passions invoked by the corresponding music; they thereby express that emotion visually and physically: "Beym Tanzen wird der Weg, den die Tänzer nehmen, in so fern er regelmäßig und symmetrisch ist, die Figur genennet. . . . Die Figur ist (also) eines von den Dingen, die nicht nur zur Annehmlichkeit, sondern auch zum Ausdruck und der Bedeutung des Tanzes das ihrige beyträgt.Man begreift leicht, daß der Gang der Menschen, auch in Ansehung des Weges, den sie nehmen, einigermaaßen durch das Leidenschaftliche in ihnen bestimmt wird." Sulzer, "Tanz," in Allgemeine Theorie, 4:385. 
the soul so quickly and so irresistibly," as Kirnberger explained. ${ }^{67} \mathrm{Mu}-$ sic, according to Kirnberger and many of his contemporaries, not only affects our aural sense, but its vibrations set in motion the fibres of our bodies, thereby forcing us to move in accordance with it. ${ }^{68}$ Kirnberger conceded that this alliance of physical and emotional forces meant that music, at least when allied to text, "could be used in particular for the education of man's disposition," 69 and that it "could be called upon by politics for the execution of the most important business." ${ }^{\circ}$ If Kirnberger found the power of music dangerous unless tied to a distinct meaning provided by a text, van Swieten and his adherents were true champions of instrumental music. For those who believed in the congruence of beauty and virtue, and in man's ability to process both the beautiful and the good through their effect on the innate moral sentiment, a text was unnecessary, but active engagement with the art object was essential. The mediation of sentiments with reason replaced the prescribing influence of words as the means to harness the power of music to the benefit of individuals and society.

The idea that engaging with art involved an inner physical act that might be intensified if it were also enacted physically was rooted in models of the interaction of body and mind that persisted in popular belief, even though they were being reconsidered in medical discourses. The passions remained central to an individual's physical and emotional life, producing an inextricable bond between body and soul, physicality and emotions. ${ }^{71}$ The integration of body and mind implied that

67 "Man wird von keiner andern Kunst sehen, daß sie sich der Gemüther so schnell und so unwiderstehlich bemächtigt." Sulzer, "Musik," in Allgemeine Theorie, 3:432.

68 "Es ist nicht möglich sie anzuhören, ohne ganz von dem Geiste der darin liegt, beherrscht zu werden: man wird wider Willen gezwungen, das, was man dabey fühlt, durch Gebehrden und Bewegung des Körpers auszudrücken." Sulzer, "Musik," in Allgemeine Theorie, 3:427.

69 "Aber da die mit Uebereinstimmender körperlicher Bewegung begleitete Musik lebhaften Eindruck macht, der Tanz aber schicklich ist, mancherley leidenschaftliche und sittliche Empfindungen zu erweken, so wird diese Gattung der Musik nicht unwichtig, und könnte besonders auch zur Bildung der Gemüther angewendet werden." Sulzer, "Musik," in Allgemeine Theorie, 3:431.

$7^{\circ}$ "Aus allen diesen Anmerkungen folget, daß diese göttliche Kunst von der Politik zu Ausführung der wichtigsten Geschäfte könnte zu Hülfe gerufen werden. Was für ein unbegreiflicher Frevel, daß sie blos als ein Zeitvertreib müßiger Menschen angesehen wird! Braucht man mehr als dieses, um zu beweisen, daß ein Zeitalter reich an Wissenschaft und mechanischen Künsten, oder an Werken des Witzes, und sehr arm an gesunder Vernunft seyn könne?" Sulzer, "Musik," in Allgemeine Theorie, 3:434.

${ }^{71}$ Bound Alberti, "Emotions in the Early Modern Medical Tradition," 7-16. The commingling of the mechanical model of the body with the humoral theories on the origins of the emotions is most obvious in performance treatises of the early and mideighteenth century. See also Thomas Dixon, From Passions to Emotions (Cambridge: Cambridge University Press, 2003), esp. chap. 3, "From Movements to Mechanisms: Passions, Sentiments and Affections in the Age of Reason," 62-97. Van Swieten's connection to the 
physical motion, i.e., action, was controlled by the passions, so that an external physical action was inspired by an internal physical alteration of the body and vice versa. This can be read not least in the eighteenthcentury rekindling of the classical subject of physiognomy, which was based in the idea that emotions and characters ingrain themselves onto physical features through the body's repeated striking of particular emotional expressions. ${ }^{72}$ In fact, eighteenth-century thinkers went beyond the classical tradition to claim that striking particular physical poses could actually induce the correlating emotional state. ${ }^{73}$ This was explained by the notion that emotional judgments were formed in the heart, not the mind, and were therefore unmediated by reason. Instead, they were a direct consequence of an inner physical movement caused by some form of stimulation. As a result, philosophers and theologians continued to tie emotion to physicality in their concern with developing rational models for understanding the emergence of human thought and feeling. Such medical models of man's irritability translated into the cultural belief in and celebration of man's sensibility. ${ }^{74}$

\section{Conclusion: Art as Education of the Sociable Sentiment}

In "Ueber die Bildung des Geschmacks," van Swieten compared the engagement with "classics" to "the social interaction (Umgang) with men of great merit and of a noble way of life." 75 In other words, he considered these works models of virtue, wisdom, and social decorum. His comparison with Umgang reinforces that it was only an active engagement with these works that would convey their benefit to the recipient: the inner sensation of taste is best inspired by the recipient's socializing with and through the work. In this telling comparison van Swieten revealed one more philosophical debt: his belief in an innate sociable sentiment. ${ }^{76}$

medical world was considerable not least because his father, Gerhard van Swieten, had revolutionized the Viennese medical school in the mid eighteenth century.

$7^{2}$ Ittershagen, Lady Hamiltons Attitüden, $15^{-20 .}$

73 This idea was developed most prominently by Henry Home, Lord Kames in Britain. See also Andrew Seth Pringle Pattinson, Scottish Philosophy: A Comparison of the Scottish and German Answers to Hume (189o; facs. repr., New York: Garland, 1983).

74 For an overview of this process, see Barker-Benfield, The Culture of Sensibility and H. N. Gardiner et al., Feeling and Emotion: A History of Theories (New York: American Book Co., 1937).

75 "Diese Schriften sind wie der Umgang mit Männern von grossen verdiensten und einer edlen Art zu leben." Van Swieten, "Ueber die Bildung des Geschmacks.”

$7^{6}$ The discussions on sociability as an innate human desire are introduced and summarized in Otto Gierke, Natural Law and the Theory of Society, trans. Ernst Barker (Boston: Beacon Press, 1957), and in Richard Tuck, Natural Rights Theories: Their Origin and Development (Cambridge: Cambridge University Press, 1979). Among historians, the still dominant view of van Swieten's achievements is that of R. Kink and H. Wolfsgruber in the 
Sulzer had already explained the relationship between the innate sentiments of sociability and morality: "Man possesses two innate abilities that are seemingly independent of each other: reason and the moral sentiment, both of which must be developed as the basis for the blissful happiness of social life." 77 Sulzer had implied here that the individual was naturally inclined toward a social life, and he had already suggested that education toward the fulfillment of the individual's natural social desire was best achieved through art. Whereas reason, according to Sulzer, was amply nurtured through the institutionalization of teaching, the schooling of moral sentiment was frequently neglected, its significance for society overlooked. ${ }^{78}$

It was van Swieten's project to address this neglect. Through educational reform, and also through engagement with literary culture, art, and music, he sought to create individuals who would recognize their citizen status as both the driving force and the reward for their actions because it coincided with their natural need for sociability. The belief in an innate moral sense tied to an innate sociability, which granted the natural disposition toward common rather than individual goals, was the key with which van Swieten could liberate teaching from the shackles of censorship. He believed that ultimately everyone would recognize the notion that the common good is greater than the interest of the individual. Morals could be taught not by prescribing them, but by honing the innate faculties of reason and moral sentiment, and by exercising the interaction between them. Leading individuals to induce their own moral code would ensure a sense of freedom and empowerment, and it would manifest ethical behavior with a greater force than was available through prescriptive teaching. His belief in the individual's innate qualities elicited the shift in focus onto process and method.

Van Swieten's Sunday salon pursued cultural, educational, and artistic ideals that in theory transcended social classes and political boundaries. Music-making was not a trifling accompaniment to social banter

mid to late nineteenth century; here, van Swieten is portrayed as a stern believer in bureaucracy, whose sole intention was to educate individuals into becoming obedient civil servants. Such discussion disregards the philosophical ideologies, particularly concerning sociability, that formed the basis for van Swieten's education system. See Rudolf Kink, Geschichte der Kaiserlichen Universität Wien (Vienna, 1854; repr. Frankfurt: Minerva-Verlag, 1969), and Cölestin Wolfsgruber, Christoph Anton Kardinal Migazzi, Fürsterzbischof von Wien (Saulgau: Kitz, 189o).

77 "Der Mensch besitzet zwey, wie es scheinet, von einander unabhängige Vermögen, den Verstand und das sittliche Gefühl, auf deren Entwicklung die Glückseligkeit des gesellschaftlichen Lebens gegründet werden muß.” Sulzer, Allgemeine Theorie, 1:xii.

$7^{8}$ "Zur Wartung des Verstandes hat man Ueberall große und kostbare Anstalten gemacht; desto mehr aber hat man die wahre Pflege des sittlichen Gefühles versäumet." Sulzer, Allgemeine Theorie, 1 :xiii. 
or a prelude to more serious discussion; rather it offered the opportunity for an essential practical engagement with colleagues in keeping with van Swieten's equation of education with interaction-i.e., with dialogue in multiple guises. For him, education was a threefold process comprising the act of thinking, critique, and the acquisition of knowledge. Whereas the first stage was necessarily solitary, he demanded that the second be interactive in order to reach a valuable result in the final stage. He considered that last stage to be innately communal in accordance with man's natural disposition toward society. Art answered the call for teaching material suited to active engagement, but this art had to be divorced from ingrained habits and established fashions. Moreover, it would prove most powerful if its action on the inner senses were neither obstructed nor restricted by the concepts conveyed in texts.

In this light, the fashion for large-scale vocal works arranged for purely instrumental ensembles takes on new significance. Key to the battle over instrumental music throughout the eighteenth century was the notion that music was judged against the demand that art should educate socially and morally. As long as this moral education remained dogmatically tied to precise concepts conveyed in words-ultimately the virtues of Scripture-and as long as these words and concepts were to present reason with a means to control the innate passions, instrumental music's effects could be considered on a scale from meaningless to pernicious. If, however, such moral concepts became brittle and questionable values, then instrumental music would take on new significance by virtue of its immediate appeal to the inner sentiments, guided by the individual's innate sense of taste.

The Creation was a manifestation of the beautiful and the sublime, and its colors and effects were praised by countless reports. The capacity of an arranger to capture its effects and colors was of concern to Haydn and to Silverstolpe, and it is to us. However, this is not the sine qua non that we might assume it to be. The essential characteristic of arrangements in general was that they brought great works of art-those that might otherwise have been experienced only passively-into a medium that allowed pleasurable recollection, the mediation of emotion with reason through enactment and physicality, and the honing of taste through active engagement. Arrangements of vocal works for instruments more particularly exploited the fact that music spoke physically by acting directly on the performers' and listeners' nerves and fibres. Arrangements thus reduced the music to its physically effective essence, relegating the moral concepts of texts to a secondary status: the moral concepts of narratives were superseded by the belief that the music's beauty, its concords and discords, would stir the inner moral sense in a positive manner. The Creation was modeled on an archaic genre, the 
ortatorio, which for van Swieten represented the ancient unity of beauty, truth, and the good. The arrangements for string quartet and string quintet allowed the exegesis of the unfamiliar model through the familiar conversational genre commonly played in the salon. If we consider further that the act of playing these pieces engaged and exercised the individual's innate sense of sociability, then the arrangements emerge as essential tools toward the establishment of an enlightened society.

University of Southampton

\begin{abstract}
Art played a significant part in the educational ideal promoted by German intellectuals in the late eighteenth century. Gottfried van Swieten, President of the Court Commission for Education in Vienna and librettist for The Creation, was instrumental in developing and promoting the role of art in the moral education of the individual. His encouragement of active engagement with art sheds new light on the common practice of arranging musical "classics" - in particular large-scale vocal works-for smaller instrumental forces around 180o. Van Swieten's writings suggest that such arrangements may be understood not merely as entertaining trifles but as the product of the sociopolitical mores of the Enlightenment.

Inviting the direct, interactive experience of art, the arrangement of Joseph Haydn's Creation for string quintet was particularly suited to the moral and social education of the individual. Grounded at least in part in archaic compositional practices, it demonstrated an artwork's adaptability to different circumstances of performance and to the different levels of education of its performers. Moreover, the act of playing the arrangement, one to a part, allowed for the honing of an individual's inner sociable sentiment through collaboration with fellow performers.
\end{abstract}

Keywords: arrangement, Joseph Haydn, moral education, taste, The Creation, Gottfried van Swieten 